
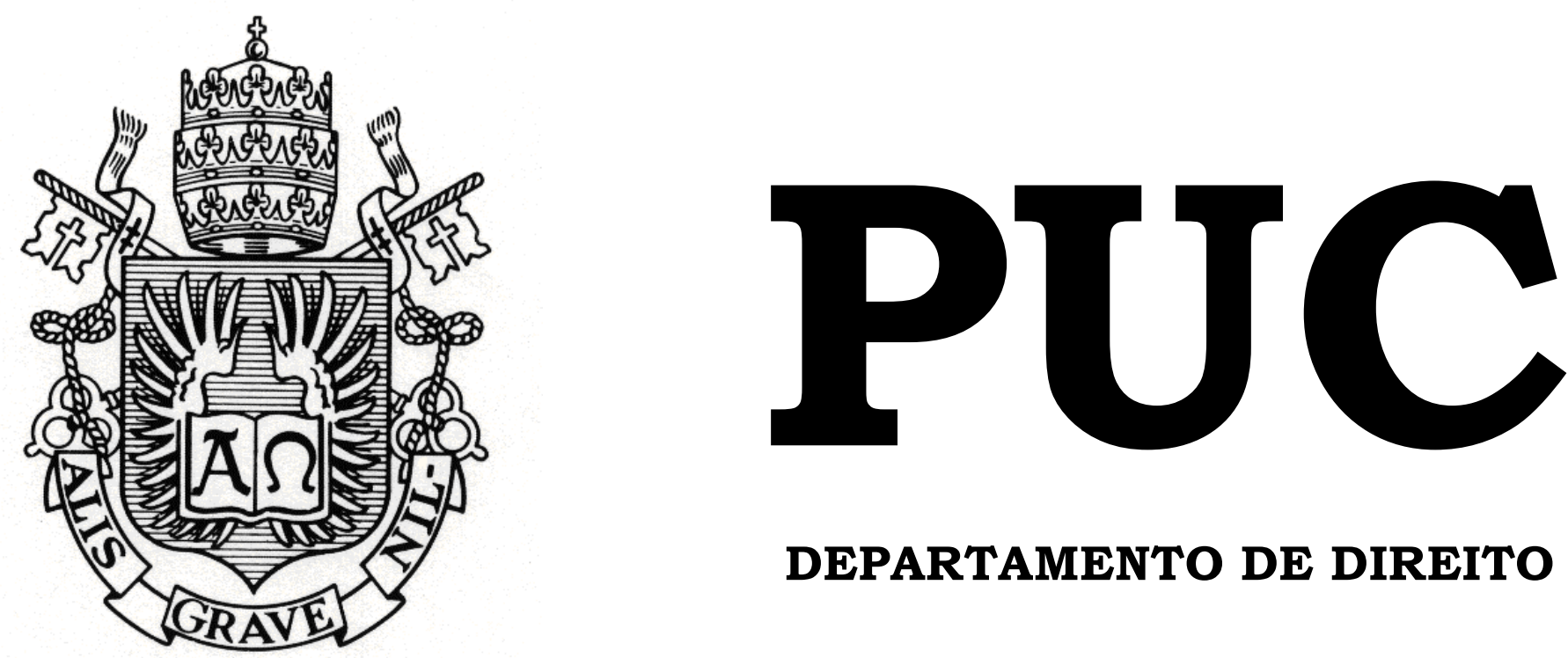

DEPARTAMENTO DE DIREITO

Poluição Atmosférica e a Resolução CONAMA 315/02: limites e possibilidades na celebração de compromisso de ajustamento de conduta

por

Pedro Henrique Ramos Prado Vasques

ORIENTADOR(A): Danielle de Andrade Moreira 2009.1

PONTIFÍCIA UNIVERSIDADE CATÓLICA DO RIO DE JANEIRO RUA MARQUÊS DE SÃO VICENTE, 225 - CEP 22453-900 RIO DE JANEIRO - BRASIL 


\section{Poluição Atmosférica e a Resolução CONAMA 315/02: limites e possibilidades na celebração $d$ compromisso de ajustamento de conduta}

por

Pedro Henrique Ramos Prado Vasques

Monografia

apresentada

ao

Departamento de Direito da Pontificia Universidade Católica do Rio de Janeiro (PUC-Rio) para a obtenção do Título de Bacharel em Direito.

Orientador(a): Danielle de Andrade Moreira 


\section{Resumo}

A presente tese tem como objetivo debater a controversa utilização do instituto do compromisso de ajustamento de conduta no âmbito das ações civis públicas que buscavam garantir a implementação da etapa P-6 do PROCONVE. Este debate tem início através de uma breve análise acerca da poluição atmosférica, seu histórico, importância e consequências para o homem e meio ambiente. Em seguida, o referido instituto é sucintamente estudado através da apresentação de suas principais características e controvérsias. Destaca-se ainda neste capítulo a importância a atuação do Ministério Público na defesa dos direito difusos, como também sua participação ao longo da celebração do compromisso. Por fim, o estudo teórico dos capítulos anteriores é confrotado com o acordo que pôs fim às referidas ações civis públicas. Busca-se nesse momento analisar se as obrigações negociadas respeitaram ou não os limites legais que autorizam a utilização do instituto do compromisso de ajustamento e a responsabilidade dos participantes no que se refere às consequências da celebração do acordo.

PALAVRAS-CHAVE: Poluição, Ar atmosférico; Compromisso de ajustamento de conduta; Resolução CONAMA 315/02; PROCONVE; Ação civil pública. 


\section{Sumário}

Introdução 4

1. Meio ambiente poluição atmosférica 6

1.1. Evolução dos conceitos e instrumentos do direito ambiental..........................6

1.2. Direito à saúde e sua relação com a poluição atmosférica ............................ 10

1.3. As consequências advindas da poluição do ar................................................ 13

1.4. A intervenção do Estado para a proteção do ar atmosférico ........................... 18

2. O instituto do compromisso de ajustamento de conduta .............................24

2.1. Breves considerações acerca da ação civil pública.......................................22

2.2. A legitimidade dos órgãos públicos legitimados para celebrar compromisso de

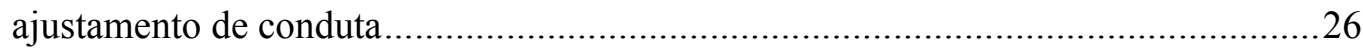

2.3. A natureza jurídica do compromisso de ajustamento de conduta.....................30

2.4. O limite de atuação das partes durante a celebração do compromisso de

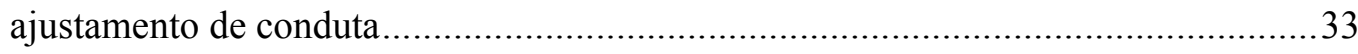

2.5. Efeitos e obrigações decorrentes da celebração do compromisso de ajustamento de conduta

3. A aplicação do compromisso de ajustamento de conduta nas ações civis públicas ajuizadas pelo Ministério Público Federal...............................................40

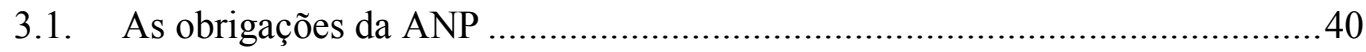

3.2. As obrigações das refinarias de petróleo, em especial da Petrobrás................42

3.3. As obrigações dos fabricantes de motores e montadoras de veículos...............44

3.4. O compromisso de ajustamento de conduta tomado pelo Ministério Público

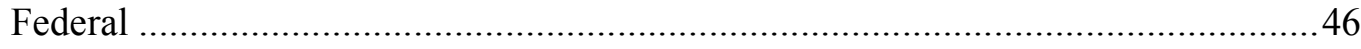

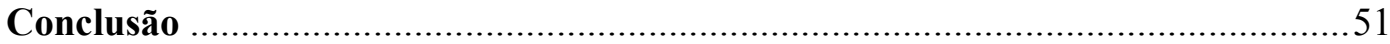

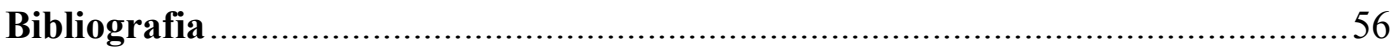




\section{Introdução}

$\mathrm{O}$ presente trabalho tem como objetivo estudar o instituto do compromisso de ajustamento de conduta e as conseqüências da sua controversa aplicação no acordo que alterou o cronograma fixado pela Resolução CONAMA 315/02, que instituiu a fase P-6 do Programa de Controle da Poluição do Ar por Veículos Automotores ("PROCONVE").

$\mathrm{O}$ tema aqui abordado merece destaque, uma vez que a poluição atmosférica é responsável por milhares de mortes todos os anos no Brasil, especialmente nas capitais, onde a utilização de veículos movidos a diesel dá-se em larga escala. Assim, o não cumprimento das obrigações trazidas pela Resolução CONAMA 315/02 afeta diretamente a qualidade de vida de grande parte da população brasileira.

Deste modo, para melhor analisar as questões aqui apresentadas, o trabalho foi dividido em três etapas.

Na primeira, é traçado, ainda que superficialmente, um esboço do problema da poluição atmosférica, seu histórico, sua importância e conseqüências, tanto para vida humana, como para o meio ambiente.

Em seguida, a ação civil pública é abordada com a finalidade de analisar a possibilidade de utilização do instituto do compromisso de ajustamento de conduta, estudado através da apresentação de seus conceitos e principais controvérsias. Destaca-se, ainda neste capítulo, a importância da atuação do Ministério Público na defesa dos direitos difusos, bem como a sua participação na realização do compromisso.

No terceiro estágio, as definições teóricas apresentadas no ponto anterior são confrontadas com o acordo responsável pela alteração do cronograma da fase P-6 do PROCONVE. Neste momento busca-se analisar se as obrigações negociadas respeitaram ou não os limites legais que autorizam a utilização do instituto do compromisso de ajustamento de 
conduta. Avalia-se também a responsabilidade dos participantes no que se refere às conseqüências da assinatura do compromisso. 


\section{Meio ambiente e poluição atmosférica}

\subsection{Evolução dos conceitos e instrumentos do Direito Ambiental}

No início da década de 70, após duas revoluções industriais, a preocupação para com o meio ambiente tornou-se objeto de amplo debate ao redor do globo. A crescente necessidade de discutir os problemas que vinham surgindo da degradação ambiental culminou com a realização da Conferência das Nações Unidas sobre Meio Ambiente Humano ("Conferência de Estocolmo"), no ano de 1972.

A partir dos princípios e definições aprovados pela Declaração de Estocolmo, foi possível identificar uma mudança progressiva na orientação das políticas públicas e privadas adotadas em diversos países que, ao reconhecerem de imediato a importância do tema, iniciaram medidas para conter a degradação do meio ambiente.

Dentre os avanços obtidos na Conferência de Estocolmo destaca-se a formulação do conceito do "direito à sadia qualidade de vida". ${ }^{1}$ A partir deste raciocínio, a idéia de conservação da vida se tornou apenas mero pressuposto para buscar o justo direito a uma saudável qualidade de vida.

Entretanto, para que essa garantia possa ser de fato alcançada, é necessário que haja plena harmonia entre homem e natureza, fazendo com que nem sempre o homem ocupe o centro das políticas ambientais. Deste modo, a Declaração de Estocolmo também tratou desta relação em seus Princípios $4^{2}$ e $5^{3}$ ao determinar que a exploração dos recursos do planeta

\footnotetext{
${ }^{1}$ Princípio 1 - O homem tem o direito fundamental à liberdade, à igualdade e ao desfrute de condições de vida adequadas em um meio ambiente de qualidade tal que lhe permita levar uma vida digna e gozar de bem-estar, tendo a solene obrigação de proteger e melhorar o meio ambiente para as gerações presentes e futuras. A este respeito, as políticas que promovem ou perpetuam o apartheid, a segregação racial, a discriminação, a opressão colonial e outras formas de opressão e de dominação estrangeira são condenadas e devem ser eliminadas.

${ }^{2}$ Princípio 4 - homem tem a responsabilidade especial de preservar e administrar judiciosamente o patrimônio da flora e da fauna silvestres e seu habitat, que se encontram atualmente, em grave perigo, devido a uma combinação de fatores adversos. Conseqüentemente, ao planificar o desenvolvimento econômico deve-se atribuir importância à conservação da natureza, incluídas a flora e a fauna silvestres.
} 
seja feita de maneira sustentável. Assim, foram dados os primeiros passos para o desenvolvimento sustentável.

Apesar de a postura adotada pelo Brasil ter sido de resistência às propostas de contenção do crescimento, em momento algum, houve manifestação contrária à adoção de medidas referentes ao desenvolvimento sustentável. Pelo contrário, até 1972, o Brasil já possuía importantes mecanismos de regulação ambiental que foram desenvolvidos após a edição do Código Civil de 1916, como por exemplo, o Decreto n. 24.643/34 (“Código de Águas"), a Lei n. 4.504/64 ("Estatuto da Terra”), a Lei n. 4.771/65 (“Código Florestal”) e o Decreto-Lei n. 227/67 (“Código de Mineração").

A crescente identificação da necessidade de se proteger o meio ambiente culminou, em âmbito nacional, com a edição da Constituição Federal de 1988. Pela primeira vez, o constituinte brasileiro alocou um capítulo específico para o meio ambiente na Carta Magna, e em seu art. 225 elevou o meio ambiente ao status constitucional, determinando à coletividade e ao Poder Público o dever de defendê-lo e preservá-lo. O pioneiro dispositivo constitucional além de tornar o meio ambiente figura jurídica própria, definiu responsabilidades específicas ao Poder Público como, por exemplo, controlar a produção, a comercialização e o emprego de técnicas, métodos e substâncias que comportem risco para a vida, a para saúde e para o meio ambiente. ${ }^{4}$ Estabeleceu também que a obrigação de

\footnotetext{
${ }^{3}$ Princípio 5 - Os recursos não renováveis da terra devem empregar-se de forma que se evite o perigo de seu futuro esgotamento e se assegure que toda a humanidade compartilhe dos benefícios de sua utilização.

${ }^{4}$ Art. 225. Todos têm direito ao meio ambiente ecologicamente equilibrado, bem de uso comum do povo e essencial à sadia qualidade de vida, impondo-se ao Poder Público e à coletividade o dever de defendê-lo e preservá- lo para as presentes e futuras gerações. $\S 1^{\circ}$ - Para assegurar a efetividade desse direito, incumbe ao Poder Público: I - preservar e restaurar os processos ecológicos essenciais e prover o manejo ecológico das espécies e ecossistemas; II - preservar a diversidade e a integridade do patrimônio genético do País e fiscalizar as entidades dedicadas à pesquisa e manipulação de material genético; III - definir, em todas as unidades da Federação, espaços territoriais e seus componentes a serem especialmente protegidos, sendo a alteração e a supressão permitidas somente através de lei, vedada qualquer utilização que comprometa a integridade dos atributos que justifiquem sua proteção; IV - exigir, na forma da lei, para instalação de obra ou atividade potencialmente causadora de significativa degradação do meio ambiente, estudo prévio de impacto ambiental, a que se dará publicidade; V - controlar a produção, a comercialização e o emprego de técnicas, métodos e substâncias que comportem risco para a vida,
} 
reparar os danos causados independe das sanções penais e administrativas, que podem ser imputadas tanto à pessoa física como jurídica.

Não obstante a criação de um capítulo específico, é possível identificar a proteção ao meio ambiente sadio permeando a Constituição Federal de 1988 como um todo. Um importante exemplo dessa afirmação pode ser identificado por meio da inclusão da defesa do meio ambiente como princípio da ordem econômica brasileira. Essa opção do constituinte pode ser considerada um dos principais avanços da Constituição de $88 \mathrm{em}$ relação à tutela ambiental, pois seu alcance e sua inclusão como limitação à livre iniciativa podem ter inúmeros e complexos desdobramentos. ${ }^{5}$

Basta que qualquer atividade econômica (pública ou privada) desconsidere a necessidade de se proteger o meio ambiente para que estejam em desconformidade com a Constituição. Do mesmo modo, a propriedade privada deixará de cumprir sua função social toda vez que se insurgir contra o meio ambiente.

Faz-se necessário destacar que apesar de toda a discussão sobre efetividade e eficácia dos dispositivos ambientais constitucionais, não há dúvida acerca de sua plena eficácia e auto-aplicabilidade, não sendo necessária a existência de qualquer norma infraconstitucional para que operem efeitos no mundo jurídico. Essa ressalva é de extrema importância, pois o constituinte, ao editar o dispositivo em questão, procurou garantir que, ainda que inexista norma infraconstitucional, toda a sociedade brasileira deverá agir no sentido de garantir que o direito ao meio ambiente sadio possa ser plenamente usufruído por todos. ${ }^{6}$

Sendo assim, fica evidente que a inexistência de dispositivo legal acerca de determinado assunto jamais poderá ser considerada empecilho

a qualidade de vida e o meio ambiente; VI - promover a educação ambiental em todos os níveis de ensino e a conscientização pública para a preservação do meio ambiente; VII - proteger a fauna e a flora, vedadas, na forma da lei, as práticas que coloquem em risco sua função ecológica, provoquem a extinção de espécies ou submetam os animais a crueldade.

${ }^{5}$ SILVA, José Afonso da. Direito ambiental constitucional. $7^{\mathrm{a}}$ ed. São Paulo: Editora Malheiros, 2009, pp. 43-53.

${ }^{6}$ FIORILlo, Celso Antonio Pacheco. Principios do direito processual ambiental. $3^{\mathrm{a}}$ ed. rev., atual. e ampl.. São Paulo: Editora Saraiva, 2009, pp. 32-50. 
para garantir a manutenção do meio ambiente sadio; do mesmo modo, em tempo nenhum poderá ser considerada justificativa para eventual excludente de responsabilidade ou justificativa para a não realização de determinada obrigação.

Mesmo antes da promulgação da Constituição Federal de 1988, diversos mecanismos legais procuravam garantir a proteção do meio ambiente, como por exemplo, a Lei n. 6.938, de 31.08.81, que criou a Política Nacional do Meio Ambiente ("PNMA").

A PNMA foi responsável por definir importantes conceitos. Entre eles destaca-se a própria definição de meio ambiente: "conjunto de condições, leis, influências e interações de ordem física, química e biológica, que permite, abriga e rege a vida em todas as suas formas".

Outro ponto fundamental abordado no art. $3^{\circ}$ da PNMA foi a criação do conceito de poluição, possibilitando, já nesse momento, concluir que os níveis de emissão produzidos pelas fontes poluidoras constituíam exemplos de poluição. A $\mathrm{PNMA}^{8}$ traz ainda, no inciso IV do artigo acima citado, a definição de poluidor, entendido como: "pessoa física ou jurídica, direito público ou privado, responsável, direta ou indiretamente, por atividade causadora de degradação ambiental". Somente através da solidificação destes e de outros conceitos é que foi possível determinar diretrizes gerais para traçar um caminho capaz de atingir o equilíbrio entre o desenvolvimento socioeconômico e a proteção ambiental, assim como para determinar os responsáveis pelo eventual descumprimento das exigências legais. ${ }^{9}$

\footnotetext{
${ }^{7}$ Art. $3^{\circ}$, I da Lei n. 6.938/81 - Para os fins previstos nesta Lei, entende-se por: I - meio ambiente, o conjunto de condições, leis, influências e interações de ordem física, química e biológica, que permite, abriga e rege a vida em todas as suas formas;

${ }^{8}$ Art. $3^{\circ}$, III, e), da Lei 6.938/81 - Para os fins previstos nesta Lei, entende-se por: III - poluição, a degradação da qualidade ambiental resultante de atividades que direta ou indiretamente: e) lancem matérias ou energia em desacordo com os padrões ambientais estabelecidos;

${ }^{9}$ ANTUNES, Paulo de Bessa. Direito Ambiental. $8^{\mathrm{a}}$ ed. rev., atual. e ampl.. Rio de Janeiro: Editora Lumen Juris, 2005, pp. 69-90.
} 


\subsection{Direito à saúde e sua relação com a poluição atmosférica}

A promulgação da Constituição Federal de 1988 foi responsável por trazer significativo avanço na história brasileira ao definir a dignidade da pessoa humana como fundamento da República Federativa do Brasil. O constituinte, ao redigir o art. $196^{10}$ da Carta Magna, inovou ao estabelecer a saúde como direito de todos e dever do Estado. Em outras palavras, o Texto Maior determina que deverá, em qualquer hipótese, haver acesso universal e igualitário às ações e serviços para promoção, proteção e recuperação deste direito. Em hipótese alguma poderá o Estado beneficiar ou permitir que se beneficie determinada parcela da população brasileira em detrimento de outra. ${ }^{11}$

Todavia, para compreender os limites desse direito faz-se necessário definir o conceito de saúde.

O marco teórico-referencial do conceito de saúde foi erigido em 26.07.46, após a Segunda Guerra Mundial, no preâmbulo da Constituição da Organização Mundial da Saúde (“OMS”) que define saúde como: “estado de completo bem-estar físico, mental e social e não apenas a ausência de doenças". A elaboração deste conceito alargou a definição de saúde, que anteriormente se restringia aos aspectos curativos e preventivos.

Apesar de a definição elaborada pela OMS sofrer inúmeras críticas em função de depender de uma série de decisões no que se refere à sua aplicação (i.e., a partir do momento que o Estado passar a ser o um dos fatores principais na promoção de saúde, a vontade política pode ser identificada como instrumento de inaplicabilidade do conceito da OMS),

\footnotetext{
${ }^{10}$ Art. 196. A saúde é direito de todos e dever do Estado, garantido mediante políticas sociais e econômicas que visem à redução do risco de doença e de outros agravos e ao acesso universal e igualitário às ações e serviços para sua promoção, proteção e recuperação.

${ }^{11}$ MARTINS, Wal. Direito à saúde: compêndio. Belo Horizonte: Editora Fórum, 2008, pp. 41-66.
} 
esta avançada concepção foi responsável por trazer a idéia de promoção de saúde e não meramente a ausência de doenças. ${ }^{12}$

A busca pela saúde, por sua vez, caracteriza-se por um processo dinâmico, que não possui definições estáticas e permanentes. Isto se dá em função do avanço contínuo das diversas áreas as quais a saúde se relaciona, como por exemplo, a evolução social e tecnológica.

Juridicamente, pode-se entender o direito à saúde, como um direito que perpassa todas as gerações. Isto quer dizer que, esta garantia constitucional pode ser classificada tanto como um direito individual de primeira geração, pois é direito de cada brasileiro ter livre acesso na procura dos serviços que melhor garantam sua saúde. Como também poderá ser qualificada como de terceira geração, em função de inexistir determinação acerca de seus titulares e ser bem difuso.

Por fim, a Declaração Universal dos Direitos Humanos, em seu art. $25,{ }^{13}$ se refere à saúde como sendo elemento de cidadania, sem a qual o indivíduo fica impossibilitado de exercer integralmente seus direitos e fruir das demais garantias.

Como visto anteriormente, o art. 225 da Carta Magna de 88, elemento essencial para a busca de sadia qualidade de vida, possui eficácia plena e aplicabilidade imediata. O mesmo se dá no que tange ao art. 196, que trata do direito à saúde ${ }^{14}$, que em determinadas circunstâncias poderá

12 SCHWARTZ, Germano. Direito à saúde: efetivação em uma perspectiva sistêmica. Porto Alegre: Livraria do Advogado, 2001, pp. 27-87.

${ }^{13}$ Artigo 25. 1. Toda pessoa tem direito a um padrão de vida capaz de assegurar a si e a sua família saúde e bem estar, inclusive alimentação, vestuário, habitação, cuidados médicos e os serviços sociais indispensáveis, e direito à segurança em caso de desemprego, doença, invalidez, viuvez, velhice ou outros casos de perda dos meios de subsistência fora de seu controle. 2. A maternidade e a infância têm direito a cuidados e assistência especiais. Todas as crianças nascidas dentro ou fora do matrimônio, gozarão da mesma proteção social.

14 Característica essa reconhecida pelo Supremo Tribunal Federal na decisão do Agravo Regimental em Agravo de Instrumento n. 238.328-0, Rel. Min. Marco Aurélio, j. 16.11.99, DJ 18.02.00, ao afirmar que o preceito do art. 196 da Constituição Federal de 88 é de eficácia imediata. Igual é o entendimento do Superior Tribunal de Justiça, que no Recurso Ordinário em Mandado de Segurança n. 11183/PR, Rel. Min. José Delgado, j. 22.08.00, DJ 04.09.00, decidiu que "despicienda de quaisquer comentários a discussão a respeito de ser ou não a regra dos arts. $6^{\circ}$ e 196, da CF/88, normas programáticas ou de eficácia imediata. Nenhuma regra hermenêutica pode sobrepor-se ao princípio maior estabelecido, em 1988, na Constituição Brasileira (...)”. 
até mesmo ser oponível contra o Estado, caso este seja considerado omisso no seu dever de proteção.

Por conseguinte, a lesão à saúde da população através da contaminação do ar atmosférico caracteriza-se por violação a direito fundamental do homem. Por sua vez, conforme previsão constitucional, é dever do Estado adotar políticas sociais e econômicas voltadas para a redução do risco de doenças.

Deste modo, para que seja possível proteger esse bem jurídico será inevitavelmente necessário que o Estado intervenha na regulação da atividade econômica. Em outras palavras, será inconstitucional toda política pública econômica que ignore ou minimize a importância desse preceito. ${ }^{15}$

Apesar de o Estado estar intimamente vinculado à responsabilidade de proteger este bem jurídico, também cabe à iniciativa privada zelar por este direito fundamental. Essa determinação está expressa nos incisos V e VI art. 170 da Constituição Federal. ${ }^{16} \mathrm{O}$ ente privado deverá, no exercício de sua atividade, respeitar, dentre outros, os princípios da defesa do consumidor e da defesa do meio ambiente, sob pena de ferir direito constitucional fundamental, atentando contra a dignidade da pessoa humana.

\footnotetext{
${ }^{15}$ Sobre este assunto, o Supremo Tribunal Federal, no Recurso Extraordinário 271-286-AgR, Rel. Min. Celso de Mello, j. 12.09.00, DJ 24.11.00, decidiu que: “O Poder Público, qualquer que seja a esfera institucional de sua atuação no plano da organização federa brasileira, não pode mostrar-se indiferente ao problema da saúde da população, sob pena de incidir, ainda que por censurável omissão, em grave comportamento inconstitucional. A interpretação da norma programática não pode transformá-la em promessa constitucional inconseqüente. $\mathrm{O}$ caráter programático da regra inscrita no art. 196 da Carta Política - que tem por destinatários todos os entes políticos que compõem, no plano institucional, a organização federativa do Estado brasileiro - não pode converter-se em promessa constitucional inconseqüente, sob pena de o Poder Público, fraudando justas expectativas nele depositadas pela coletividade, substituir, de maneira ilegítima, o cumprimento de seu impostergável dever, por um gesto irresponsável de infidelidade governamental ao que determina a própria Lei Fundamental do Estado (...)”.

${ }^{16}$ Art. 170. A ordem econômica, fundada na valorização do trabalho humano e na livre iniciativa, tem por fim assegurar a todos existência digna, conforme os ditames da justiça social, observados os seguintes princípios: V - defesa do consumidor; VI - defesa do meio ambiente, inclusive mediante tratamento diferenciado conforme o impacto ambiental dos produtos e serviços e de seus processos de elaboração e prestação;
} 
Para que a promoção da saúde seja integralmente concretizada, é fundamental que tanto o Poder Público, como o setor privado atuem em conjunto.

A necessidade desta atuação cooperativa identifica-se claramente no que se refere à política de proteção do ar atmosférico. Ainda que o Estado fixe os mais diversos padrões de qualidade do ar, se não o fizer aliado à realidade do setor privado envolvido, as normas criadas fatalmente serão descumpridas. Entretanto, se houver a participação de todos os agentes envolvidos, com a fixação de prazos e padrões coerentes, não haverá justificativa para o não cumprimento das determinações legais.

A ausência de regulação do Estado ou até mesmo o descumprimento de políticas públicas por parte do setor privado pode ensejar verdadeiro retrocesso ao direito à saúde. Situação esta inadmissível, vez que o art. 60, $\S 4^{\circ}, \mathrm{IV}^{17}$ da Carta Magna de 88 confere caráter de cláusula pétrea, ou seja, cláusula proibitiva de retrocesso social sanitário. ${ }^{18}$

A conseqüência direta de eventual retrocesso, no que tange a este direito fundamental, significa, para grande parte da população dos centros urbanos, redução da qualidade de vida. Responsável por inúmeras conseqüências negativas, não só para a saúde humana, a poluição do ar deve ser vista como um grave problema das metrópoles brasileiras.

\subsection{As conseqüências advindas da poluição do ar}

No que se refere à proteção do ar atmosférico, a PNMA, em seu art. $2^{\circ}, \mathrm{II},{ }^{19}$ define a racionalização do uso ar como princípio a ser seguido.

\footnotetext{
${ }^{17}$ Art. 60. A Constituição poderá ser emendada mediante proposta: $\S 4^{\circ}$ - Não será objeto de deliberação a proposta de emenda tendente a abolir: IV - os direitos e garantias individuais.

18 LOVATO, Luiz Gustavo. A proteção à saúde no Brasil: aspectos sociais, econômicos e políticos. In: ASSIS, Araken de. (coord.). Aspectos polêmicos e atuais dos limites da jurisdição e do direito à saúde. $1^{\mathrm{a}}$ ed.. Rio Grande do Sul: Editora Notadez, 2007, pp. 113-135.

19 Art. $2^{\circ}$ - A Política Nacional do Meio Ambiente tem por objetivo a preservação, melhoria e recuperação da qualidade ambiental propícia à vida, visando assegurar, no País, condições ao desenvolvimento sócio-econômico, aos interesses da segurança nacional e à proteção da dignidade
} 
Tamanha é a importância deste bem difuso que o legislador optou por erigir o referido dispositivo ao grau de princípio, ou seja, mecanismo responsável por nortear a interpretação das diversas normas ambientais, a fim de garantir uma saudável qualidade do ar.

Identificada a relevância deste bem ambiental, faz-se necessário apresentar os conceitos e definições de ar atmosférico e poluição atmosférica, para que seja possível relacioná-los aos inúmeros problemas que podem surgir em função de sua degradação.

De acordo com José Afonso da Silva ${ }^{20}$, é possível definir o ar atmosférico como: "uma mistura gasosa que envolve a terra, ventos, brisa e aragem, e espaço acima do solo". A poluição atmosférica por sua vez caracteriza-se, principalmente, pelo lançamento de elementos estranhos à composição desse meio.

Sob o enfoque biofísico-químico, a manutenção de um padrão de qualidade do ar atmosférico é condição sine qua non para a sobrevivência das espécies. Na medida em que se constitui no mais essencial recurso para a manutenção da vida e também por estar disponível na natureza de forma livre, o ar atmosférico deve ser visto como o bem ambiental por excelência. ${ }^{21}$

Enquanto bem jurídico, o ar atmosférico possui natureza de bem difuso ambiental. Como dito anteriormente, pertence a todos e a manutenção de certo nível de pureza é pressuposto essencial para que seja possível usufruir de uma sadia qualidade de vida.

da vida humana, atendidos os seguintes princípios: II - racionalização do uso do solo, do subsolo, da água e do ar;

${ }^{20}$ SILVA, José Afonso da. Direito ambiental constitucional. $7^{\mathrm{a}}$ ed.. São Paulo: Editora Malheiros, 2009, pp. 109-110.

21 "Comparando com outras necessidades da vida, o ar tem um consumo contínuo obrigatório, sendo essencial para os sentidos da visão, olfato e audição. Um homem adulto requer diariamente cerca de $15 \mathrm{~kg}$ de ar, $1,5 \mathrm{~kg}$ de alimento sólido e 2 l de água. Essa quantidade diária de ar inspirado entra em contato com $70 \mathrm{~m}^{2}$ de superficie alveolar, nos pulmões. Estima-se que uma pessoa não possa viver cinco semanas sem alimento, cinco dias sem água, mas não mais do que cinco minutos sem ar." DERÍSIO, José Carlos. Introdução do controle de poluição ambiental. $1^{\mathrm{a}}$ ed.. São Paulo: CETESB, 1992, p. 110. 
Em função da necessidade contínua de manter a qualidade do ar atmosférico aceitável, foram criados mecanismos para medir o nível de poluição atmosférica. Esta medição dá-se através da quantificação das substâncias poluentes encontradas no ar examinado.

Segundo José Afonso da Silva, é possível identificar a ocorrência de poluição atmosférica:

Quando a presença de uma substância estranha ou uma variação importante na proporção de seus constituintes é suscetível de provocar um efeito prejudicial ou de criar uma moléstia, tendo em conta os conhecimentos científicos do momento. ${ }^{22}$

Dentre os diversos meios de poluição, a degradação do ar atmosférico se destaca por trazer uma série de conseqüências negativas não só para a saúde humana, mas também para o patrimônio histórico e cultural e para o meio ambiente em si. Destaca-se, por exemplo, o agravamento de doenças respiratórias, a alteração na capacidade de fotossíntese dos vegetais, danos à camada de ozônio, efeito estufa e o desencadeamento de fenômenos de corrosão em materiais como vidro, couro e borracha. Isso em mencionar ainda o caráter transfronteiriço deste tipo de poluição que permite que seus efeitos danosos possam ser identificados em locais muito distantes da fonte originária.

A poluição do ar atmosférico tem como principais fontes: (i) as fixas, (ou estacionárias) representadas pela a eliminação de resíduos pela indústria em geral, como por exemplo, nos casos de geração de energia elétrica, refinarias, siderúrgicas etc.; e (ii) as móveis, identificadas no produto da combustão realizada pelos veículos automotores. Ambas são responsáveis por contribuir para emissão de poluentes que atingem desde organismos menos complexos até biomas por inteiro.

Apesar de as fontes estacionárias também responderem por expressiva parte da emissão de poluentes, este trabalho limita-se a analisar - ainda sim de forma breve - apenas as fontes móveis de degradação do ar atmosférico. O motivo desta opção reside no fato de que os veículos

\footnotetext{
${ }^{22}$ SILVA, José Afonso da. Direito ambiental constitucional. $7^{\mathrm{a}}$ ed.. São Paulo: Editora Malheiros, 2009, p. 111.
} 
automotores representam, hoje, grande parte da poluição no meio urbano e a regulação dos limites da sua interferência no meio ambiente faz-se crucial para garantir uma melhor qualidade de vida. Hoje, estima-se que a frota movida a diesel que circula pela cidade de São Paulo represente $15 \%$ do total de veículos automotores e seja responsável pela maior parte da poluição. $^{23}$

Nos atuais padrões, a poluição provocada por veículos automotores mata indiretamente, em média, quase 20 pessoas por dia na região metropolitana de São Paulo, segundo estudo do Laboratório de Poluição Atmosférica da Faculdade de Medicina da USP. Este número é quase o dobro do que podia ser identificado há cinco anos graças, principalmente, ao crescimento da frota de veículos automotores, responsáveis pela emissão de $50 \%$ do material particulado fino identificado na região metropolitana de São Paulo. ${ }^{24}$

O estudo supracitado também estima que a poluição do ar atmosférico seja responsável por 13,1 mil internações por ano, somando a quantia de 334 milhões de reais, apenas na região de São Paulo. ${ }^{25}$ Apesar de a Petrobrás afirmar, em notícia veiculada na internet, que "quanto ao material particulado, que tem relação com o teor de enxofre do diesel, os índices de São Paulo estão aceitáveis, abaixo dos limites do CONAMA", ${ }^{26}$ dados do estudo acima mencionado apontam que a concentração média diária de material particulado fino inalável, em São Paulo, é quase três vezes maior do que o permitido pela $\mathrm{OMS}^{27}$

${ }^{23}$ Sobre este tema ver: CRUZ, Ana Paula Fernandes Nogueira da. A tutela ambiental do ar atmosférico. Rio de Janeiro: Editora Esplanada, 2002, pp. 53-87.

24 SANGIOVANNI, Ricardo. Poluição de carros quadriplica risco de morte. Disponível em http://www.nossasaopaulo.org.br/portal/node/2569. Acesso em 19.05.09.

${ }^{25}$ De acordo com estudo obtido pelo jornal O Estado de S. Paulo, são gastos anualmente 459,2 milhões de reais para tratar seqüelas respiratórias e cardiovasculares de vítimas de excesso de partícula fina. ESTADO, Agência. Custo da poluição é de $R \$ 14$ por segundo, diz estudo. Disponível em http://www.estadao.com.br/geral/not ger374498,0.htm. Acesso em 26.05.09.

${ }^{26}$ PETROBRÁS, Agência. Esclarecimentos sobre teor de enxofre e o óleo diesel S-50. Disponível em http://www.agenciapetrobrasdenoticias.com.br/materia.asp?id_editoria=8\&id_noticia=5932. Acesso em 19.05.09.

${ }^{27}$ Estudos recentes realizados por pesquisadores da Escola de Saúde Pública de Harvard apontam para o fato de que a exposição a poluentes de rodovias elevam a incidência de diversas doenças 
O aumento significativo da degradação do ar atmosférico por fontes móveis ocorreu em função do processo de industrialização, intensificado após a Segunda Guerra Mundial, que teve como principal conseqüência o aumento da urbanização das cidades. O Estado, por sua vez, ao vislumbrar o potencial de crescimento socioeconômico, investiu maciçamente nos setores de infraestrutura necessários para dar suporte à indústria em geral, sem questionar as conseqüências ambientais negativas advindas deste modelo de desenvolvimento. ${ }^{28}$

No Brasil, este processo pôde ser identificado por meio dos projetos desenvolvimentistas de integração nacional que promoveram, por exemplo, através do uso de rodovias, projetos de expansão para o Centro-Oeste e para a Amazônia.

Deste modo, a opção do governo brasileiro de priorizar a expansão de estradas, aliada ao intensivo processo de urbanização, ignorando inúmeros aspectos ambientais e urbanísticos, culminou não só com a saturação dos espaços urbanos como também provocou a redução significativa da qualidade de vida nestes ambientes.

A escolha de utilizar rodovias para integrar o país teve como principal conseqüência a ampliação do uso de caminhões com a finalidade principal de servir de meio para escoamento e distribuição da produção brasileira. Estes veículos, aliados aos demais automotores movidos a diesel, que diariamente circulam em ambiente urbano, acabam, em função do combustível utilizado, por causar poluição significativamente maior do que a produzida pelos automóveis movidos a gasolina e a álcool. O professor da USP Américo Kehr, coautor de estudos realizados sobre problemas causados pela poluição atmosférica, afirma que uma das principais razões

autoimunes, como por exemplo, artrite reumatóide, tireoidite crônica autoimune, vitiligo e esclerose múltipla. Pesquisadores acreditam que, de acordo com as evidências obtidas, a poluição seja capaz de influenciar o sistema imune do corpo humano, ocorrendo especialmente nos casos de exposição à solventes e à exaustão de diesel. SILVEIRA, Julliane. Poluição aumenta risco de desenvolver doença autoimune. Disponível em http://www1.folha.uol.com.br/folha/ambiente/ult10007u558384.shtml. Acesso em 19.05.09.

28 PRADO JUNIOR. Caio. História econômica do Brasil. $45^{\mathrm{a}}$ reimpr.. São Paulo: Editora Brasiliense, 1998, pp. 301-342. 
para o aumento da mortalidade causada pela poluição veicular está contida na referida opção de se utilizar prioritariamente o transporte rodoviário para movimentação de cargas. ${ }^{29}$

Apenas para ilustrar a gravidade do problema, merecem destaque os trabalhos científicos apresentados pelo Ministério Público Estadual de São Paulo na petição inicial da Ação Civil Pública n. 053.09.006711-0. ${ }^{30}$ Os estudos alertam para o fato de que as partículas atmosféricas emitidas por motores a diesel, nas cidades de São Paulo, Recife, Belo Horizonte, Rio de Janeiro, Curitiba e Porto Alegre, estão associadas à mortalidade prematura de 6.100 brasileiros ao ano (considerando apenas doenças cardiovasculares e processos obstrutivos crônicos das vias aéreas). ${ }^{31}$

\subsection{A intervenção do Estado para a proteção do ar atmosférico}

$\mathrm{Na}$ medida em que a falta de cuidado da sociedade para com a proteção do ar atmosférico tornou necessária a intervenção do Estado para garantir a preservação deste bem difuso, esse cenário obscuro, acima apresentado, foi aos poucos se tornando menos nebuloso.

O surgimento de um regramento trazido pelo Estado já podia ser identificado na comunidade internacional desde a década de 60 do século passado e relacionava essencialmente transporte à saúde e qualidade ambiental. Para citar alguns exemplos destaca-se: (i) na França, a Lei n. 61842, de 02.08.61, que determinou sanções aos que explorassem instalações sem as devidas autorizações; (ii) no Canadá, o Clean Air Act, promulgado

\footnotetext{
29 SANGIOVANNI, Ricardo. Poluição de carros quadriplica risco de morte. Disponível em http://www.nossasaopaulo.org.br/portal/node/2569. Acesso em 19.05.09.

30 Esta ação civil pública tem como objetivo questionar o acordo que alterou a fase P-6 do PROCONVE e obrigar que o Estado de São Paulo cumpra o que está determinado na Resolução CONAMA 315/02.

${ }^{31}$ Estima-se que apenas para a cidade de São Paulo este número seja de 3.000 pessoas/ano. Com base em dados do Programa de Aprimoramento as Informações de Mortalidade ("PROAIM") da Prefeitura de São Paulo. O Ministério Público Estadual ainda demonstra que a faixa de população mais suscetível aos efeitos deste tipo de poluição está contida no grupo de pessoas abaixo dos cinco anos e acima dos sessenta e cinco anos de idade, faixas etárias estas classificadas como as mais sensíveis no curso da vida humana.
} 
no dia 23.06.71, que foi responsável por criminalizar emissões acima do padrão nacional; (iii) nos Estados Unidos, o Clean Air Act, emendado em 1974, que previu diversas penas pecuniárias e de prisão para quem desrespeitar os padrões estipulados em lei; e, finalmente, (iv) a Agenda 21, que em seu Capítulo 9 ao ponderar sobre o papel fundamental que o setor de transportes desempenha no desenvolvimento social e econômico, destacou a necessidade de se analisar os sistemas de transportes existentes na direção de se obter projetos de gerenciamento mais eficazes dos sistemas de trânsito e transporte, visto que é relevante fonte de emissões atmosféricas.

No Brasil, a intervenção do Estado teve início através da criação da pioneira Portaria n. 231, de 27.04.76, do Ministro do Interior, que, ao acolher proposta do Secretário de Meio Ambiente estabeleceu padrões de qualidade do ar. Estes parâmetros serviram de orientação para a elaboração dos planos nacionais e regionais de controle de poluição do ar, com vistas ao controle de fontes de emissão de gases poluentes como os incineradores de lixo.

Dando continuidade à política brasileira para proteção do meio ambiente, em especial para o ar atmosférico, foi instituído, em 1989, o Programa Nacional de Controle da Qualidade do Ar ("PRONAR"), ${ }^{32}$ competindo ao Instituto Brasileiro do Meio Ambiente e dos Recursos Naturais Renováveis ("IBAMA") seu gerenciamento e apoio na formulação dos programas de controle, avaliação e inventário de emissões. O PRONAR foi criado tendo em vista os seguintes objetivos: (i) garantir uma melhoria na qualidade do ar, (ii) garantir o atendimento aos padrões estabelecidos, e (iii) garantir o não comprometimento da qualidade do ar em áreas consideradas não degradadas. A estratégia básica adotada pelo PRONAR

\footnotetext{
${ }^{32}$ Criado por meio da Resolução CONAMA 005, de 05.06.89.
} 
foi limitar, ${ }^{33}$ a nível nacional, as emissões de poluentes reservando o uso dos padrões de qualidade do ar somente como ação complementar.

Dentre os diversos instrumentos criados pelo PRONAR, destacamse: (i) os limites máximos de emissão; (ii) os Padrões de Qualidade do Ar; (iii) o Programa Nacional de Avaliação da Qualidade do Ar; e (iv) o PROCONVE.

O PROCONVE, criado através da Resolução CONAMA 018, de 06.05.86, ${ }^{34}$ tem como objetivo principal reduzir os níveis de emissão de poluentes por motores veiculares, especialmente nos centros urbanos. A referida resolução determina que, além dos órgãos públicos, também participarão do PROCONVE as associações representativas dos fabricantes de motores, veículos automotores, equipamentos de controle de emissão e autopeças. Em outras palavras, o Poder Público, ao criar instrumento para regular a qualidade do combustível utilizado no Brasil, procurou incluir todos agentes econômicos interessados para que pudessem opinar na elaboração das normas e fixação de limites.

Tendo em vista a impossibilidade tecnológica e temporal para adequação imediata de toda a indústria automobilística, foram elaboradas, através de inúmeras reuniões com os participantes do PROCONVE, inclusive com os representantes das indústrias automobilísticas, uma série de etapas a serem cumpridas visando à gradual redução da emissão de poluentes pelos novos modelos de veículos automotores comercializados no país.

A primeira etapa do PROCONVE perdurou até 01.01.90, e teve como principais destinatários os distribuidores de combustíveis e fabricantes de veículos automotores. A obrigação gerada nesta primeira fase

\footnotetext{
${ }^{33}$ O PRONAR ainda determinou que a fixação dos referidos limites máximos se daria em função da classificação de usos pretendidos para diversas áreas e seria mais rígido para as fontes novas de poluição. Ou seja, o Poder Público definiu que os limites de emissão jamais retrocederiam, tendo em vista que todas as atividades novas deveriam respeitar padrões mais restritos.

${ }^{34}$ A Resolução CONAMA 018/86 foi diversas vezes complementada, como por exemplo, pelas Resoluções 008/93 e 016/95.
} 
consistia na adequação dos motores, quando necessário, além da estruturação do abastecimento de combustível ao novo veículo.

Em 28.10.93, foi promulgada a Lei n. 8.723, que elevou as Resoluções do CONAMA que tratavam do PROCONVE a um novo patamar, determinando que os fabricantes de motores, montadoras veículos automotores e os fabricantes de combustíveis tomassem as providências necessárias para reduzir os níveis de emissão de poluentes nos veículos comercializados no País. A partir deste novo dispositivo legal foram traçadas metas até 01.01.02, momento este em que a totalidade dos veículos pesados movidos a Diesel comercializados no país passou a respeitar os limites definidos no art. $2^{\mathrm{o}}, \S 4^{\mathrm{o}}$, III. $^{35}$

A partir de 1997, com o início das privatizações, foi criada a Agência Nacional do Petróleo (“ANP”), instituída através da Lei n. 9.478 de 06.08.97. Dentre diversas obrigações, a ANP foi incumbida de regulamentar as diretrizes fixadas pelo CONAMA para as fases subseqüentes do PROCONVE, obrigação essa que até hoje persiste. ${ }^{36}$

Ao buscar a continuidade da aplicação das etapas do PROCONVE, o CONAMA, em 29.10.02, editou a Resolução CONAMA 315/02, que estabeleceu novos limites de emissão de poluentes a serem cumpridos até 01.01.09. E obrigou, em seu art. $15, \S 12$, que cem por cento da produção anual, por fabricante ou importador, não ultrapassasse os novos limites por

\footnotetext{
${ }^{35}$ Art. $2^{\circ}$ da Lei n. $8.723 / 93$. São os seguintes os limites e prazos que se refere o artigo anterior: $\S$ $4^{\circ}$ - Oitenta pôr cento da totalidade de veículos pesados do ciclo Diesel comercializados pelos fabricantes nacionais terão os níveis máximos de emissão de gases de escapamento reduzido, em duas etapas, conforme os limites e cronogramas especificados abaixo: II - a partir de $1^{\circ}$ de Janeiro de 2000: a) 4,0 g/kWh de monóxido de carbono (CO); b) 1,1 g/kWh de hidrocarbonetos (HC); c) 7,0 g/kWh de óxidos de nitrogênio (Nox); d) 0,15 g/kWh de partículas, a critério do Conselho Nacional do Meio Ambiente CONAMA, até o final de 1994, em função de sua viabilidade técnica. $\S 6^{\circ}$ - A partir de $1^{\circ}$ de Janeiro de 2002, a totalidade de veículos pesados do ciclo Diesel comercializados no Brasil atenderá aos membros limites de emissão de gases de escapamento definidos no $\S 4^{\circ}$, II, deste artigo.

${ }^{36}$ Art. $8^{\circ}$ A ANP terá como finalidade promover a regulação, a contratação e a fiscalização das atividades econômicas integrantes da indústria do petróleo, do gás natural e dos biocombustíveis, cabendo-lhe: IX - fazer cumprir as boas práticas de conservação e uso racional do petróleo, gás natural, seus derivados e biocombustíveis e de preservação do meio ambiente; XVIII - especificar a qualidade dos derivados de petróleo, gás natural e seus derivados e dos biocombustíveis.
} 
ela estabelecidos. Esta Resolução, conforme seu art. $22,{ }^{37}$ tomou como base os limites, métodos e procedimentos estabelecidos pela Diretiva 1999/96/CE, do Parlamento Europeu e do Conselho de 13.12.99, responsável pela implantação do chamado ciclo Euro 4 na União Européia e amplamente conhecida por todas as partes envolvidas.

Para esta nova etapa ("P-6") do PROCONVE a Resolução CONAMA 315/02 estabeleceu prazos que, como em todas as etapas anteriores, foram negociados e debatidos em reuniões em que todos os interessados, em tese, tiveram a oportunidade de participar, inclusive as entidades responsáveis por representar os fabricantes de motores e veículos automotores e os fabricantes de combustíveis. Sua implementação deveria ser iniciada em 01.01.06 garantindo que, em 01.01.09, a concentração de enxofre no óleo diesel fosse reduzida a $50 \mathrm{ppm}$, pois de outra maneira não seria possível atingir os limites estabelecidos no art. 15, §12, da Resolução CONAMA 315/02.

Todavia, em função da falta de mobilização das partes responsáveis, quais sejam, a ANP, a Petrobrás e os fabricantes de motores e veículos automotores e os fabricantes de combustíveis, ao longo do período de implementação da referida Resolução, a possibilidade de cumprir integralmente as metas estabelecidas em 2002 passou a ser questionada. No entanto, apesar de louvável a atuação do parquet, somente a partir do final do ano de 2007 passou-se a questionar a mora no cumprimento das obrigações contidas na Resolução CONAMA 315/02.

Por meio de processo investigatório, realizado através de inquérito civil, o Ministério Público Federal optou por ajuizar as seguintes ações civis públicas: n. 2007.61.00.034636-2 e n. 2008.61.00.013278-0.

\footnotetext{
${ }^{37}$ Art. 22. Os ensaios de medição de monóxido de carbono, hidrocarbonetos, óxidos de nitrogênio e material particulado no gás de escapamento de motores destinados a veículos automotores pesados do ciclo Diesel deverão ser efetuados, conforme os métodos e procedimentos estabelecidos para os ciclos ESC, ELR e ETC da Diretiva 1999/96 do Parlamento Europeu e do Conselho, de 13 de dezembro de 1999, suas sucedâneas e complementos, até a publicação de Norma Brasileira equivalente.
} 
Após uma série de discussões realizadas no âmbito das referidas ações civis públicas, chegou-se à conclusão que, tendo em vista a não execução das obrigações pelas partes conforme cronograma inicialmente estabelecido, a partir daquele momento não haveria mais tempo hábil para que a Resolução CONAMA 315/02 fosse cumprida em sua integralidade.

Em virtude deste posicionamento, foi encaminhada, ao Ministério Público Federal, proposta para realização de uma espécie de acordo judicial, o compromisso de ajustamento de conduta. 


\section{O instituto do compromisso de ajustamento de conduta}

\subsection{Breves considerações acerca da ação civil pública}

Como dito anteriormente, os dispositivos constitucionais que buscam garantir o direito ao meio ambiente sadio possuem plena eficácia. No entanto, se não houvesse direito ao processo judicial ambiental, os referidos dispositivos não passariam de norma escrita sem possibilidade de se concretizarem.

A ação civil púbica, instituída pela Lei n. 7.347, de 24.07.85 (Lei da Ação Civil Pública - "LACP"), tem como objetivo proteger diversos direitos subjetivos e deveres jurídicos relativos ao meio ambiente, consumidor e a outros interesses coletivos e difusos.

Seu desenvolvimento é fruto de transformações sociais profundas, seguidas da evolução conceitual dos direitos humanos e sua positivação. Sua implementação no direito brasileiro significa o rompimento de inúmeras barreiras, até então intransponíveis, para que à coletividade seja garantido o acesso à justiça.

$\mathrm{O}$ aumento das cidades e o surgimento de problemas coletivos que jamais poderiam ser solucionados através da clássica tutela processual encontraram na ação civil pública instrumento hábil para dirimir tais conflitos.

Embora a LACP não tenha sido a primeira a prever mecanismos processuais de defesa de interesses difusos, visto que há vinte anos já havia a previsão da ação popular através da Lei n. 4.717/65, sua criação foi sem dúvida um grande marco na tutela jurisdicional coletiva brasileira. Dentre as inovações trazidas destacam-se a legitimidade coletiva das associações da sociedade civil, a revisão dos limites da coisa julgada e a previsão de novos e inovadores poderes ao magistrado. 
Outra grande novidade trazida pela LACP foi a possibilidade de instauração de inquérito civil, conforme o art. $8^{\circ}, \S 1^{\circ}$. Por meio deste instituto o legislador procurou garantir um mecanismo formal para colheita de dados para a propositura da ação.

Apesar de o inquérito civil ser considerado ferramenta fundamental para garantir o sucesso das ações ajuizadas pelo Ministério Público, o instrumento que merece atenção neste trabalho é o compromisso de ajustamento de conduta.

Esta nova ferramenta introduzida no direito processual brasileiro possui elevada eficácia quando o objeto do título tem por escopo a proteção de bem de natureza ambiental. Isto se dá na medida em que através do compromisso de ajustamento de conduta é possível, de forma muito mais célere do que por meio da via judicial, evitar a continuidade de determinada degradação ou até mesmo evitá-la quando iminente. No que tange à manutenção do equilíbrio ecológico, é primordial, que o dano seja reparado o quanto antes e o perigo evitado, sempre que possível.

Entretanto, o compromisso de ajustamento de conduta não pode ser visto como panacéia para todas as irregularidades ambientais. A possibilidade de sua realização é determinada por lei e qualquer manifestação no sentido de ultrapassar o que foi permitido pelo legislador se mostra flagrantemente ilegal, devendo ser rapidamente sanada pelo Poder Judiciário, bem como pelos órgãos públicos legitimados.

Nesse sentido, faz-se necessário analisar determinados pontos teóricos do instituto do compromisso de ajustamento de conduta para que seja possível compreender sua questionável utilização no caso concreto objeto de análise por este trabalho. 


\subsection{A legitimidade dos órgãos públicos legitimados para celebrar compromisso de ajustamento de conduta}

A possibilidade de realização de compromisso de ajustamento de conduta foi introduzida no arcabouço jurídico brasileiro através do art. 55 da Lei n. 8.069/90 - que instituiu o Estatuto da Criança e do Adolescente. ${ }^{38}$ No entanto, foi através do art. 113 da Lei n. 8.078/90 - que aprovou o Código de Defesa do Consumidor (“CDC”), e que incluiu o $\S 6^{039}$ no art. $5^{\circ}$ da $\mathrm{LACP}^{40}$ que o compromisso de ajustamento de conduta foi incorporado como meio possível para garantir a proteção ambiental.

O instituto em questão, por ser tomado por termo, acaba também por ser conhecido no meio jurídico como termo de ajustamento de conduta.

Apesar de a LACP ter atendido à tendência moderna ao ampliar os esquemas clássicos de legitimação para garantir maior acesso à justiça, a LACP limitou apenas a determinados órgãos públicos a possibilidade de realização do compromisso de ajustamento de conduta.

Conforme dispõe o $\$ 6^{\circ}$ do art. $5^{\circ}$ da Lei n. $7.347 / 85$, terão legitimidade para tomar o compromisso de ajustamento de conduta somente

\footnotetext{
${ }^{38}$ Entretanto, alguns doutrinadores, como por exemplo, Mazzilli, identificam que o surgimento da possibilidade de realização de acordos extrajudiciais teria ocorrido por meio outras normas anteriores à Lei n. 8.069/90, como por exemplo, o art. 55 da Lei n. 7.244/84, a antiga Lei dos Juizados Especiais, que determinava que: "o acordo extrajudicial, de qualquer natureza ou valor, poderá ser homologado, no juízo competente, independentemente de termo, valendo a sentença como título executivo judicial." MAZZILLI, Hugo Nigro. Compromisso de ajustamento de conduta ambiental: evolução e fragilidades e atuação do Ministério Público. In: Revista de Direito Ambiental v. 41. São Paulo: Editora Revista dos Tribunais, 2006, pp. 96-110.

${ }^{39}$ Art. $5^{\circ} \S 6^{\circ}$ da Lei n. $7.347 / 85$. Os órgãos públicos legitimados poderão tomar dos interessados compromisso de ajustamento de sua conduta às exigências legais, mediante cominações, que terá eficácia de título executivo extrajudicial.

${ }^{40}$ Cabe uma observação no que se refere ao suposto veto presidencial ao art. $82 \S 2^{\circ}$, CDC, que trazia redação idêntica à do art. 113, do mesmo diploma legal, sendo que, nas razoes dadas pelo Presidente, este expressamente manifestou que também vetaria este último artigo da lei em comento. Porém, não o fez. Esta peculiar situação permitiu que alguns doutrinadores entendessem que de fato o referido artigo teria sido vetado, não obstante sua publicação. No entanto, os tribunais encerraram a questão, optando pela vigência do dispositivo. Neste mesmo entendimento acompanharam os seguintes julgados do Superior Tribunal de Justiça ("STJ"): REsp 443.407/SP, Rel. Min. João Otávio de Noronha, j. 16.03.06, DJ 25.04.06; REsp 418.395/MA, Rel. Min. Barros Monteiro, j. 28.05.02, DJ 16.09.02; REsp 222.582/MG, Rel. Min. Milton Luiz Pereira, j. 12.03.02, DJ 29.04.02. Entendeu do mesmo modo o Tribunal de Justiça de São Paulo (“TJSP”): AC 782.098-5/8-00, Rel. Des. Regina Capistrano, j. 29.01.09, DJ 18.02.09; EI 188.963-5/7-01, Rel. Des. Renato Nalini, j. 01.08.06, DJ 16.08.06.
} 
os órgãos públicos legitimados para propor ação civil pública. Parte majoritária da doutrina entende que o legislador utilizou a expressão “órgãos públicos legitimados" em sentido amplo, e ao fazê-lo permitiu o surgimento de algumas dúvidas acerca do rol de legitimados para propor o compromisso. $^{41}$

De acordo com Carvalho Filho, ${ }^{42}$ ao examinar a lista dos legitimados ativos presentes nos arts. $5^{\circ}$ e 82 do $\mathrm{CDC}$, identifica-se que, além dos órgãos públicos incontroversamente legitimados ${ }^{43}$ e aqueles entendidos que não podem ${ }^{44}$ tomar o compromisso, existe um terceiro grupo, composto pelas fundações públicas, autarquias, empresas públicas e sociedades de economia mista. Quanto às autarquias e fundações públicas, deve-se entender por sua legitimidade, visto que estes entes estatais estão voltados para a prática de serviços de interesse predominantemente coletivo, com fim social. Por outro lado, as empresas estatais e as sociedades de economia mista não podem ser consideradas órgãos legitimados para tomar o compromisso, pois, ainda que instituídos e mantidos pelo Poder Público, possuem personalidade jurídica de direito privado, com finalidade específica voltada para a exploração de atividade econômica. Logo, por agir nessa qualidade, não estariam aptos para tomar compromisso de ajustamento de conduta relacionado a interesses metaindividuais.

Entretanto, segundo o entendimento de Mazzilli, ${ }^{45}$ será permitido a órgãos pelos os quais o Estado administra o interesse público, ainda que

\footnotetext{
${ }^{41}$ Conforme o entendimento de Carvalho Filho é necessário fazer uma ressalva no que diz respeito ao sentido da expressão "órgãos públicos" no texto do art. $5^{\circ} \S 6^{\circ}$ da LACP. Entende o doutrinador que o legislador optou por utilizar a referida expressão em sentido mais amplo, referindo-se não somente às partes componentes das pessoas públicas, mas também as pessoas dotadas de personalidade jurídica de direito público e o Ministério Público. CARVALHO FILHO. Ação civil pública: comentários por artigo. $7^{\mathrm{a}}$ ed.. Rio de Janeiro: Editora Lumen Juris, 2009. 206 p.

${ }^{42}$ CARVALHO FILHO. Ação civil pública: comentários por artigo. $7^{\mathrm{a}}$ ed.. Rio de Janeiro: Editora Lumen Juris, 2009, pp. 219-224.

43 (i) Ministério Público, (ii) União, (iii) Estados, (iv) Municípios, (v) Distrito Federal, e (vi) órgãos públicos, ainda que sem personalidade jurídica, especificamente destinados à defesa de interesses difusos.

${ }^{44}$ (i) associações civis, (ii) sindicatos, e (iii) fundações privadas.

${ }^{45}$ MAZZILLI, Hugo Nigro. A defesa dos interesses difusos em juízo: meio ambiente, consumidor, patrimônio cultural, patrimônio público e outros interesses. $21^{\mathrm{a}}$ ed. rev., ampl. e atual.. São Paulo: Editora Saraiva, 2008, pp. 400-403.
} 
integrem a administração indireta (e. g. autarquias, fundações públicas ou empresas públicas), que tomem compromissos de ajustamento de conduta nas hipóteses em que estes órgãos ajam na qualidade de entes estatais.

Quando os órgãos estatais agirem na qualidade de exploradores da atividade econômica, não será permitido que tomem compromisso de ajustamento de conduta. De outro modo esta situação resultaria em estímulo à criação de desigualdades afrontosas à ordem jurídica.

Rodrigues, ${ }^{46}$ que alterou seu entendimento anterior, passou igualmente a acompanhar o posicionamento acima exposto. A autora também faz distinção entre as sociedades de economia mista e as empresas públicas prestadoras de serviços públicos e as exploradoras de atividade econômica. E determina que, neste caso, somente as prestadoras de serviços podem ter, entre as suas atividades, a celebração de compromisso de ajustamento de conduta.

Este trabalho opta por filiar seu pensamento na corrente acima exposta, que admite que entes estatais prestadores de serviços públicos sejam considerados legitimados para celebração de compromisso de ajustamento de conduta. Isto porque sua atividade está caracterizada pelo cumprimento da função estatal, e de forma alguma está vinculada à atividade econômica, de modo que não fomenta eventual desigualdade.

O compromisso de ajustamento de conduta, conforme idealizado, deverá sempre buscar obter os melhores resultados na conciliação entre o meio ambiente e o desenvolvimento. Deve sempre ser visto como meio para ampliar o acesso à justiça coletiva, afastando, em diversas oportunidades, o conflito judicial. O compromisso jamais poderá servir de meio para reduzir esse acesso ou servir de obstáculo para a proteção dos direitos difusos. Deste modo, tem como finalidade principal conferir à tutela metaindividual maior celeridade e eficiência, servindo como garantia mínima em proveito

\footnotetext{
${ }^{46}$ RODRIGUES, Geisa de Assis. Ação civil pública e termo de ajustamento de conduta. $2^{\mathrm{a}}$ ed.. Rio de Janeiro: Editora Forense, 2006, p. 163.
} 
da coletividade e nunca como meio de permitir concessões de direito material em favor do causador do dano.

Sob o prisma da busca pelo acesso à justiça, cabe aqui destacar a importância da atuação do Ministério Público como ente legitimado para a celebração de compromisso de ajustamento de conduta. No Brasil, o Ministério Público possui um papel marcante na defesa dos direitos difusos, em especial do meio ambiente. Esta situação é tão clara que o próprio legislador, ao romper com o modelo processual clássico através da edição da LACP, garantiu legitimação específica a esta instituição eminentemente republicana. $^{47}$

Nesse contexto, o Ministério Público deve ter sempre em mente a importância de sua atuação, especialmente quando se trata da celebração de termo de ajustamento de conduta. Esta afirmação mostra-se necessária, pois uma instituição tida como o bastião da defesa do meio ambiente deve sempre atuar de forma responsável, não autorizando em hipótese alguma que o poluidor ou aquele que permita existência de risco de dano deixe de cumprir suas obrigações legais.

Para garantir que haja uma atuação responsável por parte do Ministério Público é necessário que os membros desta instituição sempre busquem agir de forma homogênea. Isso não significa que exista qualquer pretensão de mitigação do princípio da independência funcional do Ministério Público, previsto no art. $127, \S 1^{\circ}$ da Constituição Federal de 1988. Pelo contrário, a busca por uma atuação homogênea visa garantir a integridade da própria instituição, evitando que seus atos sejam questionados em função de atuações discrepantes entre os diversos estados da Federação. ${ }^{48}$

\footnotetext{
${ }^{47}$ Não há que se discutir a legitimidade do Ministério Público no que tange à defesa de direitos difusos. Jurisprudência do STJ é pacífica no sentido de garantir a possibilidade de o parquet realizar a defesa de interesses coletivos (cf. STJ. AgREsp n, 170.958/SP Rel. Min. Franciulli Netto, j. 18.03.04, DJ 30.06.04; Resp 310.703/SP Rel. Min. Eliana Calmon, j. 26.11.02, DJ 16.12.02; e Resp 265.358/SP Rel. Min. Humberto Gomes de Barros, j. 04.09.01, DJ 18.02.02).

48 Neste mesmo diapasão deverão se pautar os demais órgãos públicos legitimados para a celebração de termo de ajustamento de conduta.
} 
Todavia, caso a atuação do Ministério Público Federal se mostre insuficiente para garantir a proteção de determinado direito difuso, terá o Ministério Público Estadual competência para ajuizar nova ação civil pública nos limites do que não foi protegido, e vice-versa. Faz-se imperioso lembrar que apesar de o mecanismo ser inovador e incentivar uma atuação preventiva por parte do Poder Público, o compromisso de ajustamento de conduta deve necessariamente sofrer um intensivo controle $^{49}$ sobre sua legalidade e validade para que não se distancie de seu objetivo principal que é a proteção dos direitos difusos. Não sendo dispensado, de forma alguma, o controle exercido pela coletividade, que pode a todo o momento questionar a validade dos compromissos de ajustamento de conduta tomados pelos órgãos públicos legitimados.

\subsection{A natureza jurídica do compromisso de ajustamento de conduta}

Ainda que pouco abordado pela doutrina administrativista, o surgimento do instituto do compromisso de ajustamento de conduta foi possível somente através de uma gradual mudança na interpretação dos princípios do Direito Administrativo. A relação do Poder Público com a sociedade, no que tange ao exercício do poder de polícia, era inicialmente, via de regra, regida pela unilateralidade, inviabilizando qualquer discussão ou flexibilização na sua aplicação.

Hoje, por outro lado, com o surgimento de novos instrumentos para solução de conflitos como, por exemplo, o próprio compromisso de ajustamento de conduta, pode-se identificar situações nas quais a unilateralidade é mitigada, abrindo caminhos capazes de afastar, ainda que parcialmente, a obrigatoriedade do exercício do poder de polícia. Seguindo

\footnotetext{
49 Entende-se por controle o conceito desenvolvido por Odete Medauar: "controle da Administração Pública é a verificação da conformidade da atuação desta a um cânone, possibilitando ao agente controlador a adoção de medida ou proposta em decorrência do juízo formado." MEDAUAR, Odete. Controle da administração pública. $1^{\text {a }}$ ed. São Paulo: Editora Revista dos Tribunais, 1993, p. 22.
} 
este entendimento, Di Pietro explica que os meios de coação devem ser utilizados apenas quando não houver outro meio eficaz para alcançar o mesmo objetivo. ${ }^{50}$

Caso a realização de compromisso de ajustamento de conduta se mostre mais eficiente que qualquer outro meio possível de ser utilizado pela administração pública, o uso do poder de polícia acaba por se tornar ineficaz. Assim, sua eventual aplicação excederia os limites conferidos aos atos administrativos.

Em relação à natureza jurídica do compromisso de ajustamento de conduta a doutrina diverge em inúmeros aspectos. Pode-se exemplificar tal dissonância através da apresentação do posicionamento de alguns autores. Milaré $^{51}$ em seu livro defende a tese de que o instituto em questão foi consagrado como figura peculiar de transação, na medida em que não só pode prevenir o litígio como também pode pôr-lhe fim. No mesmo sentido entende Fink, ${ }^{52}$ que identifica o compromisso como transação de caráter contratual, que deverá seguir no que couber, a legislação civil. Machado, ${ }^{53}$ por sua vez, o qualifica como uma espécie de acordo, entendido que o termo "transação" induziria a uma interpretação que possibilitaria o despojamento de direitos indisponíveis. Seguindo a mesma linha, Akaoui ${ }^{54}$ define o compromisso como espécie do gênero "acordo" em que a liberdade do órgão público fica restrita apenas à forma pela qual se darão as medidas corretivas e o tempo. Já Mazzilli ${ }^{55}$ entende que, o instituto deve ser

\footnotetext{
${ }^{50}$ O Poder Público deverá observar determinadas regras com o fim de não eliminar os direitos individuais, entre elas destacamos a regra da eficácia, que determina que a medida adotada pelo Poder Público deve ser adequada para impedir o dano ao interesse público. PIETRO, Maria Sylvia Zanella di. Direito administrativo. $21^{\mathrm{a}}$ ed. São Paulo: Editora Atlas, 2008, p. 105.

${ }^{51}$ MILARÉ, Édis. Direito do ambiente: doutrina, jurisprudência, glossário. $4^{\mathrm{a}}$ ed. rev., atual. e ampl.. São Paulo: Editora Revista dos Tribunais, 2005, pp. 954-956.

${ }^{52}$ FINK, Daniel Roberto. Alternativa à ação civil pública ambiental: reflexões sobre as vantagens do termo de ajustamento de conduta. In: MILARÉ, Édis (coord.). Ação Civil Pública - Lei 7.347/85 - 15 anos. São Paulo: Editora Revista dos Tribunais, 2001, pp. 119-120.

${ }_{53}$ MACHADO, Paulo Affonso Leme. Direito Ambiental Brasileiro. $13^{\mathrm{a}}$ ed. rev., atual. e ampl.. São Paulo: Malheiros: 2005, pp. 362-363.

${ }^{54}$ AKAOUI, Fernando Reverendo Vidal. Compromisso de ajustamento de conduta ambiental. $2^{\mathrm{a}}$ ed. rev. e atual.. São Paulo: Editora Revista dos Tribunais, 2008, pp. 70-71.

${ }^{55}$ MAZZILLI, Hugo Nigro. A Defesa dos interesses difusos em Juizo. $21^{a}$ ed. rev., ampl. e atual.. São Paulo: Saraiva, 2008, p. 404.
} 
classificado como ato administrativo negocial através do qual apenas o causador do dano se compromete, o órgão público que celebra o compromisso a nada se obriga, exceto, implicitamente, a não propor ação de conhecimento para pedir aquilo que já está reconhecido no título. E finalmente, Rodrigues ${ }^{56}$ conclui que o compromisso de ajustamento de conduta seria um negócio jurídico bilateral da Administração, pois, para a autora, a bilateralidade é essencial em função de não ser permitido que órgão público legitimado realize o compromisso consigo, celebrando espécie de "auto-ajustamento".

Apesar de todas as teses acima apresentarem argumentos mais que defensáveis, o presente trabalho opta por filiar seu entendimento junto ao pensamento de Carvalho Filho. ${ }^{57}$ Segundo o referido doutrinador, o compromisso de ajustamento de conduta possuirá natureza de ato jurídico unilateral no momento da manifestação volitiva do interessado, pois o ânimo de realizar um compromisso de ajustamento de conduta deve partir somente do infrator. Neste sentido, o interessado jamais poderá impor ao Poder Público a obrigação de realizar o compromisso. No momento de sua formalização, entretanto, o célebre autor entende que o ato jurídico será bilateral, ${ }^{58}$ pois neste momento participará tanto o promitente quanto o Poder Público.

Cabe ressalvar que, independentemente dos múltiplos posicionamentos doutrinários aqui apresentados, o Superior Tribunal de Justiça tem adotado a corrente que entende ser o compromisso uma modalidade de transação. ${ }^{59}$

${ }^{56}$ RODRIGUES, Geisa de Assis. Ação civil pública e termo de ajustamento de conduta. $2^{\mathrm{a}}$ ed.. Rio de Janeiro: Editora Forense, 2006, p. 152.

${ }^{57}$ CARVAlHO FILHO, José dos Santos. Ação civil pública: comentários por artigo. $7^{\mathrm{a}}$ ed. ampl. e atual.. Rio de Janeiro: Editora Lumen Juris, 2009, pp. 219-241.

58 Acompanha este entendimento o seguinte acórdão: TJSP. Apelação Cível sem Revisão n.788.941-5/0-00, Rel. Des. Regina Capistrano, j. 18.12.08, DJ 30.01.09.

${ }_{59}$ STJ. $2^{\mathrm{a}}$ T. REsp 299.400/RJ, Rel. Min. Francisco Peçanha Martins, j. 01.06.06, DJ 02.08.06. Ementa: PROCESSO CIVIL - AÇÃO CIVIL PÚBLICA POR DANO AMBIENTAL AJUSTAMENTO DE CONDUTA - TRANSAÇÃO DO MINISTÉRIO PÚBLICO POSSIBILIDADE. 1. A regra geral é de não serem passíveis de transação os direitos difusos. 2. Quando se tratar de direitos difusos que importem obrigação de fazer ou não fazer deve-se dar tratamento distinto, possibilitando dar à controvérsia a melhor solução na composição do dano, 


\subsection{O limite de atuação das partes durante a celebração do compromisso de ajustamento de conduta}

Visto que o órgão público legitimado atuará somente na fase de formalização do compromisso, deve ficar claro que, em momento algum, se comprometerá. Pelo contrário, quem assumirá obrigações será o interessado, que deseja adequar sua conduta às exigências legais. Merece observação o fato que, apesar de parte da doutrina ${ }^{60}$ acreditar que a realização do compromisso implica verificação expressa de culpa pela prática da conduta ajustada, este trabalho se filia à corrente que identifica como desnecessária a assunção de culpa por parte do interessado.

Como dito anteriormente, no seu momento de formalização, o compromisso de ajustamento de conduta possui natureza bilateral. Neste momento, são identificados dois participantes, quais sejam: (i) compromitente e (ii) o compromissário. O primeiro é aquele que assume o compromisso de restaurar a legalidade de determinada conduta. Sua participação é simultaneamente material, pois é ele quem assume as obrigações contidas no compromisso, e formal, tendo em vista a necessidade de sua manifestação volitiva para formalizar o instrumento.

O segundo participante é o órgão público legitimado para tomar o compromisso. Sua atuação é meramente formal e em nenhum momento deverá expressar sua vontade material, pois o conteúdo do compromisso deve sempre se resumir às obrigações que o compromitente assumirá.

Ao longo do processo de negociação do compromisso de ajustamento de conduta será permitido ao órgão público legitimado determinar apenas a forma pela qual se darão as medidas corretivas e o tempo. No que tange ao conteúdo do compromisso, é vedado aos órgãos

quando impossível o retorno ao status quo ante. 3. A admissibilidade de transação de direitos difusos é exceção à regra. 4. Recurso especial improvido.

${ }^{60}$ RODRIGUES, Geisa de Assis. Ação civil pública e termo de ajustamento de conduta. $2^{\mathrm{a}}$ ed.. Rio de Janeiro: Editora Forense, 2006, p. 157. 
públicos legitimados deliberar sobre uma possível alteração do dispositivo legal violado.

Esta limitação faz-se necessária, pois, como é sabido, os interesses difusos singularizam-se por sua indisponibilidade. Portanto, torna-se impossível conceber que interesse metaindividual indivisível, cujo titular é a coletividade, possa ser negociado por um determinado sujeito em prejuízo dos demais. Não é permitido, nesse sentido, que o Poder Público ao tomar o compromisso renuncie a direito material sob pena de desvirtuar o verdadeiro sentido do instituto em debate. ${ }^{61} \mathrm{Ou}$ seja, a celebração de acordo que determine a redução da poluição de determinado rio, a veiculação de propaganda menos enganosa, ou a distribuição de produto menos prejudicial à saúde, etc., é nitidamente um absurdo, ${ }^{62}$ visto que há que se garantir a integral proteção, preservação e/ou reparação do bem difuso violado ou na iminência de sê-lo. Qualquer compromisso que admita o descumprimento expresso ou implícito de obrigação legal é nulo, portanto, não possui eficácia.

Apesar de, via de regra, o compromisso ser considerado bilateral em sua fase de formalização não se pode afastar a necessidade de intervenção do Ministério Público, quando for tomado através da via judicial. Seja quando for autor da ação civil pública, seja quando atuar como fiscal da lei, a sua intervenção é sempre obrigatória quando não figurar como parte. ${ }^{63}$ Segundo o entendimento de Carvalho Filho ${ }^{64}$, a presença do Ministério Público não é obrigatória nos casos de compromisso de ajustamento de conduta tomado extrajudicialmente. Esta situação se justificaria em virtude

\footnotetext{
61 Importante destacar o Enunciado n. 01/2005 da $4^{\text {a }}$ Câmara de Coordenação e Revisão do Ministério Público Federal, que em seu enunciado determina: "Termos de Ajustamento de Conduta que violem dispositivo legal não são passíveis de homologação, a exemplo dos que visam a regularizar intervenções em Área de Preservação Permanente."

${ }^{62}$ Parte da doutrina defende que um acordo que admita o descumprimento expresso ou implícito das obrigações legais é nulo, logo não possui eficácia. MACHADO, Paulo Afonso Leme. Direito Ambiental Brasileiro. 13a ed. rev., atual. e ampl.. São Paulo: Malheiros: 2005, p. 364.

${ }^{63}$ Art. $5^{\mathrm{o}}$ Têm legitimidade para propor a ação principal e a ação cautelar: I - o Ministério Público; $\S 1^{\circ} \mathrm{O}$ Ministério Público, se não intervier no processo como parte, atuará obrigatoriamente como fiscal da lei.

${ }^{64}$ CARVALHO FILHO, José dos Santos. Ação civil pública: comentários por artigo. $7^{\mathrm{a}}$ ed. ampl. e atual. Rio de Janeiro: Editora Lumen Juris, 2009, p. 228.
} 
de o art. $5^{\circ}, \S^{\circ}$ da LACP restringir a atuação do Ministério Público ao processo. Em momento algum, segundo o referido autor, o legislador exigiu que o compromisso de ajustamento de conduta ficasse condicionado à intervenção do Ministério Público para ser qualificado como título executivo extrajudicial.

Ainda que não seja permitido dispor acerca de direitos difusos, a realização do compromisso gera uma obrigação implícita ao Poder Público de não utilizar o poder de polícia no que tange àquelas condutas objeto do compromisso. Através da realização do compromisso, o órgão público legitimado irá dispor de titulo executivo, faltando-lhe, assim, interesse processual para promover eventual ação de conhecimento. Por sua vez, a ilicitude das condutas negociadas no compromisso persistirá até que atendam às exigências legais. Apenas após verificação por parte do órgão público legitimado do cumprimento integral de todas as obrigações acordadas é que será possível conseguir a quitação do compromisso de ajustamento de conduta.

Independentemente da natureza jurídica do instituto estudado, reitera-se a necessidade de ter sempre em mente que o compromisso só estará atendendo plenamente ao seu objetivo se for um meio econômico, breve e justo de solução de conflito coletivo. Deste modo, não é permitido que se crie excessivo formalismo para a celebração do ajuste, fato este que inviabilizaria o instrumento como forma auxiliar de solução de conflitos.

\subsection{Efeitos e obrigações decorrentes da celebração do compromisso de ajustamento de conduta}

Apesar de o art. $5^{\circ}, \S 6^{\circ}$, da LACP se referir apenas à formação de título extrajudicial em seu texto, é pacífico o entendimento de que o compromisso poderá ser tomado tanto extrajudicialmente, quanto durante a realização de ação civil pública. No entanto, para que o acordo seja 
realizado em juízo, será necessário que haja homologação judicial para que o compromisso seja válido e forme título executivo judicial. Se, porventura, o acordo não abranger todos os elementos do direito protegido, permanecerá a possibilidade de ajuizamento de nova ação civil pública por outro órgão público legitimado. A via judicial permanecerá aberta, neste caso, pois, conforme dito anteriormente, o compromisso tem a função de servir como garantia mínima, sendo impossível que este sirva de instrumento para impedir qualquer co-legitimado, mesmo após a realização, de buscar a defesa de interesse difuso. ${ }^{65}$ Entende-se que o núcleo central do compromisso será o cumprimento de obrigação de fazer ou não fazer. Essas obrigações deverão estar sempre condicionadas ao objetivo principal que é a adequação às exigências legais. Admite-se, porém, que o instituto possua caráter indenizatório, mas este sempre terá origem subsidiária e estará vinculado ao compromisso principal, ou seja, a promessa de que a conduta se adequará à lei. Quanto à previsão pecuniária, entende-se possível somente quando esta versar sobre penas impostas pelo atraso ou não cumprimento do que foi estipulado no compromisso.

No que se refere às obrigações de fazer, não restam dúvidas de que constituem importante mecanismo de tutela do meio ambiente, posto que estarão vinculadas a projetos voltados para a reparação de eventual degradação. Entretanto, ao optar por celebrar compromisso que contemple obrigações de fazer, o Poder Público deve estar atento a fim de verificar se as medidas adotadas pelo interessado serão de fato eficazes para reparar o bem ambiental tutelado, sob pena de configurar descumprimento do compromisso.

Também são de suma importância as obrigações de não fazer. Apesar de tradicionalmente ser conceituada como aquela em que o sujeito

\footnotetext{
${ }^{65}$ Como alternativa ao ajuizamento de nova ação civil pública, na hipótese de o compromisso não contemplar integral adequação às exigências legais, existe possibilidade de se ajustar o acordo incluindo novas obrigações, garantindo assim que ele abarque todas as condutas necessárias de ajuste. Esse ajuste poderá ser feito pelo próprio núcleo que negociou sua primeira versão ou por qualquer outro órgão público legitimado.
} 
passivo deve omitir o ato em todas as ocasiões em que poderia realizá-1o, ${ }^{66}$ na defesa do meio ambiente as obrigações de não fazer têm o condão de fazer cessar a atividade poluidora. As obrigações de não fazer também poderão possuir cunho essencialmente preventivo, já que servirão de meio para evitar que nova degradação ocorra.

Tendo em vista que a reparação do dano ao meio ambiente é feita, via de regra, mediante a recuperação do que foi degradado, deverá atingir não só o ressarcimento da lesão material, mas também da imaterial ou extrapatrimonial. As obrigações contidas no compromisso devem sempre estar orientadas no sentido de buscar a reparação integral do bem atingido. No entanto, a possibilidade de se conseguir a esperada reparação integral, permitindo o retorno ao status quo ante, torna-se impossível, dependendo da lesão. Somente quando verificada a impossibilidade de se restaurar o bem degradado será permitido utilizar medidas compensatórias. Este mesmo raciocínio deve estar presente durante a negociação de um compromisso de ajustamento de conduta, optando pela compensação apenas como último meio de solução.

O órgão público legitimado poderá concordar com prazos mais elásticos para que o interessado adote as medidas necessárias, desde que a solução alvitrada seja considerada idônea. Essa hipótese só será possível caso o interesse coletivo, mesmo com a fixação destes novos prazos, venha a ser resguardado em sua parte nuclear e substancial. De outro modo, qualquer flexibilização poderá classificar este ato como um meio escuso de negociação de direitos difusos.

A possibilidade de garantir prazos mais amplos para o cumprimento das obrigações dá-se, em grande parte, em função do entendimento que reconhece que nem todo atentado ou agressão ao meio ambiente causa necessariamente um prejuízo à qualidade ambiental. É necessário ressalvar que a tolerabilidade está intimamente vinculada a uma conduta antijurídica

\footnotetext{
${ }^{66}$ PEREIRA, Caio Mário da Silva. Instituições de direito civil. V. 2. Teoria geral das obrigações. Rio de Janeiro: Editora Forense, 2005, p. 65.
} 
suscetível de reparação. De outra forma não há que se falar neste princípio. $^{67}$

Deve-se estar atento, pois nesse caso não é necessário que a conduta antijurídica seja necessariamente contra a lei. Todas as condutas anti-sociais que lesam ou limitam o pleno desenvolvimento de qualquer indivíduo e que, portanto, desconhecem os valores constitucionais, também estão abrangidas. $^{68}$

A idéia de tolerabilidade sofre inúmeras críticas da doutrina. ${ }^{69}$ Pois, a fixação de normas e índices de emissão de poluentes, por exemplo, não considerariam aspectos de efeitos sinérgicos destes mesmos poluentes, que ao entrar em contato com outras substâncias, igualmente lançadas sob padrões fixados pelo Estado, teriam seus efeitos potencializados, provocando danos que inicialmente não eram previstos pelos mecanismos de controle.

Deste modo, ao tomar um compromisso de ajustamento de conduta, o órgão público legitimado possui o poder-dever de exercer juízo prévio de tolerabilidade. Este exercício do poder discricionário da Administração ${ }^{70}$ justifica-se pelo fato de que, neste momento, o Estado deverá sopesar todos os impactos negativos e positivos que a celebração do compromisso trará para o meio ambiente e para a sociedade.

Após o compromisso de ajustamento de conduta ter sido tomado, todas as suas determinações entram em vigor imediatamente. Contudo, tendo o legislador optado por garantir uma legitimidade disjuntiva e concorrente para o ajuizamento da ação civil pública, cabe aos demais colegitimados fiscalizar o compromisso tomado.

\footnotetext{
${ }^{67}$ MILARÉ, Édis. Direito do ambiente: doutrina, jurisprudência e glossário. $4^{\text {a }}$ ed. rev., atual. e ampl.. São Paulo: Editora Revista dos Tribunais, 2005, p. 955.

${ }^{68}$ LEITE, José Rubens Morato. Dano ambiental: do individual ao coletivo extrapatrimonial. $2^{\mathrm{a}}$ ed. rev., atual e ampl.. São Paulo: Editora Revista dos Tribunais, 2003, p. 189.

${ }^{69}$ MIRRA, Álvaro Luiz Valery. Ação civil pública e a reparação do dano ao meio ambiente. $2^{\mathrm{a}}$ ed., atual. São Paulo: Editora Juarez de Oliveira, 2004, pp. 106-107.

${ }^{70}$ A Administração deverá pautar seu juízo de valor, quanto a critérios de política de interesse público, através da consideração de aspectos técnicos, que serão apresentados por meio de estudos científicos acerca do tema. Deste modo, haverá a incidência de discricionariedade técnica e administrativa.
} 
Essa fiscalização faz-se necessária uma vez que as obrigações contidas no termo devem estar condizentes com a pretendida proteção aos direitos difusos. No caso de haver obrigação que enseje qualquer tipo de ilegalidade ou até mesmo no caso de o próprio termo ser ilegal, sua desconstituição deverá ser obtida judicialmente.

Apesar de a doutrina entender que esta desconstituição deverá ser buscada através de nova ação civil pública, ou até mesmo através de ação popular, existe decisão judicial no sentido de admitir o recurso de apelação para anular termo de compromisso. ${ }^{71}$

Feitas considerações gerais acerca do instituto do compromisso de ajustamento de conduta, passa-se a debater o termo tomado pelo Ministério Público Federal com o objetivo de adequar a conduta dos interessados aos dispositivos da Resolução CONAMA 315/02.

${ }^{71}$ TRF 4a Região. 4 $4^{a}$ T., AC n. 2005.72.00.12806-9/SC, Rel. Des. Federal Edgard Antônio Lippmann Júnior, j. 17.12.07, DJ 19.02.08. 


\section{A aplicação do compromisso de ajustamento de conduta nas ações civis públicas ajuizadas pelo Ministério Público Federal}

Antes de iniciar análise do compromisso de ajustamento de conduta firmado pelo Ministério Público Federal no âmbito das referidas ações civis públicas, será apresentado um panorama geral, destacando as obrigações de cada uma das partes do pólo passivo das ações civis públicas objeto do ajuste.

\subsection{As obrigações da ANP}

Como já mencionado, a edição da Resolução CONAMA 315/02 deu início à fase P-6 do PROCONVE. Almejando a continuidade do sucesso na aplicação do Programa, e considerando a importância da proteção do ar atmosférico, a nova etapa tornou os limites de emissão de poluentes por veículos automotores mais restritivos. Graças a esta nova limitação, o único meio atualmente possível para garantir o cumprimento dos padrões fixados na fase P-6 é a utilização óleo diesel $\mathrm{S} 50^{72}$ por novos veículos, adaptados para o novo combustível. ${ }^{73}$

Desde 1986, quando foi instituído o PROCONVE, todos os órgãos e entidades envolvidas vinham respeitando integralmente o processo de melhoria na qualidade dos motores e do óleo diesel. Em alguns casos, o cumprimento dos prazos fixados se deu até mesmo de forma antecipada, como por exemplo, no caso da Petrobrás, que iniciou a implementação da Resolução CONAMA 373/06 antes de sua regulamentação pela ANP.

\footnotetext{
${ }^{72}$ A sigla S50 indica que o diesel em questão possui 50 partes por milhão de enxofre. Da mesma forma, S500 determina que o referido combustível possua em sua composição 500 partes por milhão de enxofre.

${ }^{73}$ Estudo elaborado pela IPT/SPTrans/Fundação Hewlett demonstrou que a substituição do óleo diesel 500 ppm (S500) pelo diesel 50 ppm (S50) nas frotas antigas em uso reduziu a emissão de material particulado em até $60 \%$.
} 
Entretanto, em 2006, a ANP, que, como já destacado, possuía a obrigação de regulamentar as diretrizes fixadas pelo CONAMA, deixou de fazê-lo, dando assim o primeiro passo na direção de inviabilizar o cumprimento da Resolução CONAMA 315/02. A omissão da ANP, ao deixar de regular norma que tem por objeto a proteção de diversos direitos fundamentais (e. g. direito à saúde, ao meio ambiente ecologicamente equilibrado), é o mesmo que atacar a diretamente a Carta Magna de 1988.

Somente diante da pressão exercida pela sociedade civil ao denunciar as conseqüências trazidas pela utilização do óleo diesel tipo S500 é que, em 2007, a ANP editou a Resolução n. 32. Contudo, a referida resolução nada regulamentou. Pelo contrário, a ANP ignorou o calendário estabelecido pela Resolução CONAMA 315/02 desde 2002 e condicionou, em seu art. $3^{\text {o }}{ }^{74}$ o fornecimento do óleo diesel S50 à adequação logística. Porém o prazo legalmente determinado para fornecimento do novo combustível em momento algum foi atrelado a condicionantes estabelecidas por terceiros (i. e. adequação logística).

No que diz respeito à data de fornecimento do diesel para realização de testes, a referida Resolução da ANP também ignorou o calendário previsto pela Resolução CONAMA 315/02. Inicialmente, o fornecimento deveria começar em 01.01.06, porém o art. $4^{\circ}$ da Resolução ANP n. $32 / 2007,{ }^{75}$ modificou seu início para o dia 16.12.07, extrapolando mais uma vez a competência da Agência, que tem função apenas de regulamentar diretrizes já fixadas pelo CONAMA e não de alterá-las. Não havia qualquer motivo para tanta demora ou alterações, já que a fase P-6 é idêntica a EURO 4, desenvolvida pela União Européia, e seguia os mesmos passos, no que tange à sua aplicação.

\footnotetext{
74 Resolução ANP 32/2007, Art. 30 - O óleo diesel S50 estará disponível comercialmente nos postos revendedores após a adequação da logística para suprimento do novo produto em todo o País.

${ }^{75}$ Resolução ANP 32/2007, Art. $4^{\circ}$ - O óleo diesel S50 para testes deverá ser disponibilizado pelos produtores ou importadores aos distribuidores para comercialização com os fabricantes de veículos automotores e de componentes em quantidades e freqüência negociadas previamente. Parágrafo único. Para ajuste ao que se dispõe no caput fica concedido prazo de até 60 dias contados a partir da data de publicação desta Resolução.
} 
Em outras palavras, por mais de um ano e meio a ANP se manteve inerte no que tange ao seu dever de regulamentar a Resolução CONAMA 315/02 e quando finalmente editou resolução para tratar do tema o fez de forma precária e insuficiente caracterizando verdadeira omissão de sua parte. Desse modo, a edição da Resolução n. 32 serviu apenas de argumento para que as demais partes se utilizassem a fim de se escusarem do cumprimento de suas obrigações.

Apesar do descumprimento das determinações do PROCONVE por parte da ANP, essa abstenção jamais poderia servir de álibi para os fabricantes de veículos justificarem o descumprimento à Resolução CONAMA 315/02. Por mais que se defenda a tese de que o princípio da legalidade ${ }^{76}$ estaria sendo violado, o conteúdo da Resolução que a ANP deixou de regular se refere apenas a procedimentos internos tomados pela indústria e que, de forma alguma, podem ser considerados óbices no sentido de impedir que direito constitucionalmente garantido seja protegido. Esta afirmação ainda é corroborada pelo fato de que as partes envolvidas já possuíam todas as informações necessárias para implementação da Resolução CONAMA 315/02. Via de regra, a edição de resolução pela ANP, apesar de importantíssima, não passava de mero instrumento formal estipulado pela referida resolução CONAMA.

\subsection{As obrigações das refinarias de petróleo, em especial da Petrobrás}

Do mesmo modo que a abstenção da ANP não pode servir de obstáculo para defesa do bem difuso aqui defendido, as refinarias de petróleo, em especial a Petrobrás, sociedade de economia mista, sob controle da União, também não poderia se olvidar de cumprir a Resolução

\footnotetext{
${ }^{76}$ Art. $5^{\circ}$ Todos são iguais perante a lei, sem distinção de qualquer natureza, garantindo-se aos brasileiros e aos estrangeiros residentes no País a inviolabilidade do direito à vida, à liberdade, à igualdade, à segurança e à propriedade, nos termos seguintes: II - ninguém será obrigado a fazer ou deixar de fazer alguma coisa senão em virtude de lei;
} 
CONAMA 315/02, tendo em vista sua importância no processo de refino e distribuição do diesel no país. Primeiro, porque deve adequar a qualidade do diesel aos limites do PROCONVE. Segundo, pois participou das reuniões que determinaram a referida Resolução e, como dito acima, tinha pleno conhecimento do que era necessário para a implantação da fase P-6.

É obrigação de todas as refinarias de petróleo que atuam no país respeitar as diretrizes impostas pela ANP. Todavia, neste caso, não havia qualquer motivo que obrigasse as companhias a esperar por regulações específicas para que fosse possível dar início ao cumprimento de normas constitucionais. Como demonstrado no Capitulo 1, doutrina e jurisprudência entendem que os dispositivos presentes na Constituição Federal que tratam do direito ao meio ambiente ecologicamente equilibrado e do direito à saúde são auto-aplicáveis e possuem eficácia imediata. Assim sendo, a aplicação desses dispositivos jamais poderia ser condicionada à edição de Resolução pela ANP, caso contrário ficaria evidenciada absurda inversão de valores jurídicos.

Especialmente por se tratar de uma estatal, não há qualquer argumento minimamente defensável que escuse a Petrobrás do cumprimento de suas obrigações relativas à implementação da Resolução CONAMA 315/02. Isto porque o PROCONVE é instrumento que faz parte do planejamento do desenvolvimento nacional, ${ }^{77}$ possuindo assim função determinante no que tange à atuação de entes públicos, como por exemplo, a Petrobrás. $^{78}$

Em novembro de 2007, a Petrobrás passou a anunciar que iria disponibilizar o diesel S50 somente quando a indústria automobilística

\footnotetext{
${ }^{77}$ Segundo Hely Lopes Meirelles entende-se planejamento como: "o estudo e estabelecimento das diretrizes e metas que deverão orientar a ação governamental, através de um plano geral de governo, de programas globais, setoriais e regionais de duração plurianual, do orçamentoprograma anual e da programação financeira de desembolso, que são seus instrumentos básicos." MEIRELLES, Hely Lopes. Direito administrativo brasileiro. $35^{\text {a }}$ ed. São Paulo: Editora Malheiros, 2009, p. 750.

${ }^{78}$ Art. 174. Como agente normativo e regulador da atividade econômica, o Estado exercerá, na forma da lei, as funções de fiscalização, incentivo e planejamento, sendo este determinante para o setor público e indicativo para o setor privado.
} 
passasse a fabricar veículos capazes de atingir as exigências da fase P-6. A companhia alegou que a utilização de combustível de melhor qualidade em veículos com motores antigos era um erro. Todavia, mesmo se utilizado em automóveis antigos, o diesel S50 reduz, se comparado ao S500, em 60\% as emissões de material particulado. ${ }^{79}$

Por se tratar de sociedade criada e mantida pelo Poder Público, a Petrobrás, que detém $90 \%$ do mercado de diesel no Brasil, deveria ter exigido da ANP a regulamentação do combustível desde o dia 01.01.06, porém não o fez. Agiu, assim, em conluio com a ANP, contribuindo para inviabilizar o cumprimento da Resolução CONAMA 315/02.

\subsection{As obrigações dos fabricantes de motores e montadoras de veículos}

No que tange à responsabilidade dos fabricantes de motores e montadoras de veículos automotores, estas também, em hipótese alguma, poderiam deixar de cumprir as metas estabelecidas na referida Resolução CONAMA. Isto se dá em função de a Lei n. 8.723/93 determinar no parágrafo único de seu art. $7^{0^{80}}$ que, na ausência de fornecimento de combustível necessário para realização dos testes de homologação, será permitido aos fabricantes de veículos e motores a importação de óleo diesel de referência, para ensaios de emissão adequada para cada etapa.

Ao buscar garantir o cumprimento da fase P-6 algumas companhias, até mesmo antes da Resolução ANP n. 32/07, chegaram a se preparar para

\footnotetext{
79 BAHNEMANN, Wellington. Petrobrás vai reduzir enxofre no diesel. Disponível em http://www.idec.org.br/climaeconsumo/noticia.asp?id=9254. Acesso em 25.05.09.

${ }_{80}$ Lei n. $8.723 / 93$ - Art. $7^{\circ}$ Os órgãos responsáveis pela política energética, especificação, produção, distribuição e controle de qualidade de combustíveis, são obrigados a fornecer combustíveis comerciais, a partir da data de implantação dos limites fixados por esta lei, e de referência para testes de homologação, certificação e desenvolvimento, com antecedência mínima de trinta e seis meses do início de sua comercialização. Parágrafo único. Para cumprimento desta lei, os órgãos responsáveis pela importação de combustíveis deverão permitir aos fabricantes de veículos e motores a importação de até cinqüenta mil litros/ano de óleo Diesel de referência, para ensaios de emissão adequada para cada etapa, conforme as especificações constantes no anexo desta lei.
} 
atender às futuras exigências. Demonstrou-se, assim, que havia plena condição para que as demais companhias também realizassem esforços no sentido de garantir que a fase seguinte do PROCONVE fosse integralmente cumprida. Porém, o que de fato aconteceu foi o aproveitamento, por parte das fabricantes e montadoras de veículos, da omissão da ANP e da Petrobrás para justificar a impossibilidade de se adequarem aos limites estabelecidos na fase P-6. É possível chegar a essa conclusão ao verificar os seguintes fatores: (i) a nova fase não é tão complexa para indústria automobilística, como foi a P-5, que exigiu inúmeras mudanças nos veículos em questão, ${ }^{81}$ e (ii) as mesmas montadoras já respeitavam essas exigências na União Européia, quando desde 2005 o limite já era equivalente à fase P-6 brasileira.

Os fabricantes de motores e as montadoras de veículos alegaram ainda que seria impossível produzir a nova frota de automotores adequados aos novos limites, pois seriam necessários pelo menos três anos para realização de testes e desenvolvimento dos novos motores. Essa alegação também não prospera, pois a obrigação fixada em 2002 jamais foi questionada, e como acima dito, independentemente de regulação estatal as companhias possuíam meios, desde o início da implementação da Resolução CONAMA 315/02, para realizar os testes e com isso produzir a nova frota. Esta argumentação apenas demonstra que houve, por parte dessas companhias, uma omissão consciente e planejada, que levou em conta apenas seus próprios interesses financeiros, sem atentar minimamente para os riscos à saúde e ao meio ambiente.

Outro argumento que comprova tamanho descaso para com a sociedade brasileira está presente na conduta das companhias, que, ao buscarem as novas Licenças para Uso da Configuração do Veículo ou Motor (“LCVM") ${ }^{82}$ para os modelos referentes ao ano de 2009, não fizeram

\footnotetext{
${ }^{81}$ Fato este inclusive mencionado na petição inicial da ação civil pública 2007.00.61.034636-2.

${ }^{82}$ Lei n. 8.723/1993 art. $5^{\circ}$. Somente podem ser comercializados os modelos de veículos automotores que possuam a LCVM - Licença para uso da configuração de veículos ou motor, emitida pelo IBAMA.
} 
sequer um único pedido para homologação de veículos a diesel com as especificações adequadas à nova fase (P-6) a ser implantada a partir de 01.01.09. Esta conduta ficou comprovada através do Inquérito Civil Público n. 1.34.001.000679/2008-12, que constatou que as indústrias pretendiam se adequar aos limites de emissão de poluentes da fase P-6 somente ao final de 2010, sob justificativa de que a ANP havia demorado a editar a Resolução n. $32 / 07$.

Definidas as responsabilidades das partes do pólo passivo das ações civis públicas, cabe nesse momento, estudar o compromisso de ajustamento de conduta tema deste trabalho.

\subsection{O compromisso de ajustamento de conduta tomado pelo Ministério Público Federal}

A partir de uma primeira análise é possível identificar inúmeras medidas compensatórias adotadas pelas partes, com o objetivo de mitigar os efeitos da não implementação da Resolução CONAMA 315/02, como por exemplo: (i) a promoção das atividades do Programa Nacional de Racionalização do Uso dos Derivados do Petróleo e do Gás Natural ("CONPET"); (ii) o depósito de um milhão de reais para o programa de fiscalização de emissão de fumaça preta realizado pela Companhia de Tecnologia Saneamento Ambiental ("CETESB"); (iii) a antecipação da aceitabilidade dos motores para funcionarem com teores de biodiesel de até 5\%; e (iv) a realização de Campanha Educativa sobre Emissões de Veículos a Diesel.

Como dito anteriormente, a opção de utilizar medidas compensatórias deve ser sempre a última escolha, priorizando a reparação do dano, quando este já ocorreu, ou evitando que este se realize, quando ainda está na iminência de ocorrer. Ao utilizar inúmeras medidas compensatórias poder-se-ia concluir que até o momento do acordo as 
possibilidades técnicas existentes não permitiam a adequação à norma legal, logo restaria apenas a compensação para tentar recuperar o dano ambiental.

Ocorre que esta situação jamais se materializou. Como explicitado no ponto anterior, todas as partes possuiam conhecimento necessário para realizar a implementação das novas exigências, visto que participaram das reuniões de elaboração da Resolução CONAMA 315/02, que adotou quase que integralmente o conteúdo da Diretiva 1999/96/CE, do Parlamento Europeu e do Conselho de 13.12.99. Em 2006, quando deveriam ter sido iniciados testes para implementação da fase P-6, a referida diretiva já havia sido aplicada na União Européia. Em função dessa situação, toda a tecnologia necessária já havia sido desenvolvida, bastando, se fosse o caso, realizar eventuais adaptações.

Fica demonstrado, assim, que na verdade, o adiamento da implantação desta importante etapa do PROCONVE se deu meramente por conveniência das montadoras, em detrimento da vida e da saúde dos brasileiros e do meio ambiente. Este foi o ponto defendido na petição inicial ação civil pública 2007.00.61.034636-2 e que, com a realização do acordo, foi nitidamente deixado de lado.

Ao continuar o presente estudo, verifica-se que o núcleo de metas estipulado pela Resolução CONAMA 315/02, que teria como prazo para entrar em vigor o dia 01.01.09, foi postergado em mais de três anos para determinadas obrigações. Fica demonstrado, assim, que o calendário determinado pela referida Resolução foi bruscamente alterado.

É verdade que o compromisso pode dispor sobre o tempo e modo como as exigências legais serão cumpridas, porém este tempo não pode ultrapassar os limites garantidos pelo princípio da tolerabilidade. Este prazo temporal deve possuir razões que justifiquem este período. Levando em consideração os motivos que levaram ao descumprimento da Resolução em questão, não é possível encontrar justificativas suficientes que nos indiquem que o caminho tomado pelas partes levou em consideração a saúde da população brasileira e do meio ambiente. 
Analisando em específico as obrigações assumidas pela ANP identifica-se elevado grau de discricionariedade, que, a princípio, não encontra qualquer justificativa. Pode-se exemplificar tais arbitrariedades através da criação de obrigações tais como: (i) a edição de resolução que regulamente o uso do óleo diesel S50 especificamente para as regiões metropolitanas de Belém, Fortaleza e Recife, a ser ofertado a partir de 01.05.09; (ii) a edição de resolução que regulamente o uso do diesel S50 em frotas cativas de ônibus urbanos de acordo com localidades e cronogramas específicos; e (iii) a criação de plano de abastecimento que deverá prever a disponibilização de combustível prioritariamente para veículos novos e somente posteriormente para os demais veículos.

Neste momento, as partes, ao determinarem regiões e veículos preferenciais, violam diretamente a Constituição Federal. Verifica-se o retalhamento completo das obrigações listadas pela Resolução CONAMA $315 / 02$, sem que nenhuma explicação fosse dada por qualquer uma das partes sobre os motivos que as fizeram determinar que uma região precisa ser abastecida primeiro do que as demais. Ou seja, foi permitido às partes determinar quais brasileiros irão usufruir melhor qualidade do ar em detrimento de outros.

Em outras palavras, o compromisso privilegia parcela da população com base em critérios de conveniência estipulados essencialmente pelos fabricantes e montadores de veículos. A obrigação acordada ignora completamente que o destinatário da norma em questão é a população brasileira e não a indústria de automotores. Em momento algum, no ordenamento jurídico brasileiro, se vislumbra a hipótese de que apenas à determinada parcela da população seja garantido direito à saúde. A opção de firmar compromisso que crie essa distinção é flagrantemente inconstitucional, indo diretamente de encontro aos interesses da sociedade, fato este que, portanto, revela a predominância do interesse privado sobre o público. 
Restou à Petrobrás, além de medidas compensatórias, a obrigação garantir a distribuição dos combustíveis nos moldes das obrigações conferidas a ANP, como por exemplo: (i) a obrigação de distribuir o óleo diesel comercial S50 nas regiões metropolitanas de Belém, Fortaleza e Recife conforme a referida regulamentação a ser editada pela ANP; e (ii) a obrigação de substituir a oferta de óleo diesel S500 pelo diesel S50 para as frotas cativas de ônibus urbanos de acordo com localidades e cronogramas específicos.

Ficando evidenciada, novamente, flagrante violação não só ao ordenamento jurídico brasileiro, mas também aos princípios basilares que regem sua interpretação.

No que tange às responsabilidades dos fabricantes de veículos, o acordo lhes garantiu novo prazo de três anos, a partir de 01.01.09, para que realizem a adequação da produção de veículos automotores às condições necessárias para a utilização dos novos combustíveis. Como visto anteriormente, o compromisso poderá versar sobre o prazo para adequação às exigências legais, porém este prazo não pode estar alheio à realidade em que está sendo negociado.

Ao garantir à indústria o referido prazo, concluem as partes que nenhuma medida foi tomada desde 2006, seguindo o cronograma da Resolução CONAMA 315/02, ou, ainda, que nada foi feito desde 2007, após a Resolução ANP n. 32/07, fato este injustificável, especialmente sabendo que havia condições para a implementação das obrigações, mas que, por negligência dos fabricantes, nada foi feito.

A opção de garantir novo prazo de três anos para a indústria mais uma vez demonstra total descompasso entre o conteúdo do acordo e as necessidades da população brasileira, que, diante da inércia dos fabricantes de veículos, vê-se obrigada a continuar respirando ar de péssima qualidade.

Não se pode deixar de identificar que, por outro lado, o compromisso ajustado foi além e estabeleceu novo organograma para implementação do 
óleo diesel S10, assim como criou o Plano de Qualidade do Ar, medida compensatória essa já anteriormente destacada.

As referidas obrigações são de fato importantes, entretanto não significam nada além de pequenas concessões realizadas pelas indústrias, que através de um processo de negociação barganharam mais tempo e melhores condições para obrigações que já possuíam ciência desde 2002.

Ao realizar este acordo, com o objetivo de evitar um desastre ambiental, institucional e social, o Poder Público abriu precedentes para que a norma ambiental seja flexibilizada por motivos muito além do que podemos considerar justos. 


\section{Conclusão}

Mesmo antes da década 70, quando as preocupações com o meio ambiente foram tomando dimensões globais, o Brasil já alocava sua legislação ambiental infraconstitucional em posição de vanguarda internacional.

Todavia, foi por meio da elaboração da Constituição Federal de 1988 que a proteção ao direito ao meio ambiente ecologicamente equilibrado se consolidou no direito brasileiro. Desde então, a legislação ambiental foi se tornando cada vez mais complexa, buscando garantir a proteção dos diversos aspectos do meio ambiente, seja ele natural ou artificial.

A crescente industrialização do país em meados do século XX acabou por permitir uma larga expansão do meio urbano. $\mathrm{O}$ aumento das cidades trouxe também diversos problemas relacionados à poluição do meio ambiente e a redução da qualidade de vida de seus habitantes. Dentre os inúmeros obstáculos advindos deste processo de crescimento, destaca-se a degradação da qualidade do ar.

Em virtude do aumento do número de fontes poluidoras, em especial dos veículos automotores, foi possível registrar diversos fenômenos negativos relativos à degradação do ar atmosférico (e.g. a ocorrência de chuvas ácidas, o aumento de doenças cardiovasculares, danos à camada de ozônio).

Tendo em vista a importância do problema da poluição atmosférica, o legislador infraconstitucional iniciou, dentre outras medidas, a implementação do PROCONVE. Graças a este programa foi possível, por meio da melhora na qualidade dos combustíveis e motores utilizados no Brasil, reduzir consideravelmente os níveis de material particulado fino no meio urbano. 
Ocorre que, no momento em que a fase P-6 do PROCONVE, criada pela Resolução CONAMA 315/02, seria implementada, uma seqüência de acontecimentos tornaram aparentemente impossível sua aplicação.

O primeiro dos acontecimentos foi a omissão da ANP. A agência possuía o dever de regulamentar as diretrizes fixadas pelo CONAMA até o ano de 2006. Porém, sua única manifestação foi a criação de uma resolução que nada regulamentou, trazendo apenas mais dúvidas sem aludir a qualquer solução.

Por sua vez, as refinarias de petróleo, inclusive a Petrobrás, também se omitiram. Sua principal obrigação era distribuir o novo diesel para que os fabricantes de motores e montadoras de veículos pudessem realizar os devidos testes para adequação dos novos automotores. A alegação de omissão da ANP não encontra fundamento uma vez que as partes possuíam todo o conhecimento necessário para o cumprimento de suas obrigações.

Por fim, os fabricantes de motores e montadoras de veículos, em quase sua totalidade, se recusaram a adequar seus produtos às diretrizes da fase P-6. A postura omissiva adotada teria ocorrido em virtude da omissão das demais partes. Deste modo, segundo as companhias, não haveria possibilidade técnica nem econômica que pudesse adequar os veículos em um prazo de tempo tão curto. Entretanto, a própria Resolução CONAMA 315/02 já previa meios para que os fabricantes de motores e montadoras de veículos fossem capazes de garantir a implementação da nova fase caso houvesse problemas para distribuição do diesel para testes.

Em razão deste conturbado cenário, o Ministério Público Federal, por meio das ações civis públicas n. 2007.61.00.034636-2 e n. 2008.61.00.013278-0, veio requerer que as partes cumprissem suas respectivas obrigações de modo que fosse possível garantir a implementação da fase P-6 em seu cronograma original. Apesar de louvável a postura do Ministério Público, o ajuizamento das ações se deu de forma tardia, criando mais um obstáculo a fim de inviabilizar o cumprimento do cronograma da nova fase. 
O resultado desta série de acontecimentos foi a celebração de um compromisso de ajustamento de conduta. A opção das partes se deu em virtude de acreditarem que, tendo em vista o pouco tempo que lhes restavam, seria impossível cumprir as obrigações da Resolução CONAMA 315/02 no prazo legalmente previsto.

A criação do instrumento do compromisso de ajustamento de conduta se deu em função da necessidade de garantir maior celeridade à tutela ambiental. Entretanto, a principal condição para sua existência é a exigência de reparação integral dos danos causados, sendo permitido ao órgão público legitimado definir apenas o prazo e o modo do cumprimento das obrigações acordadas. Necessário destacar que a atuação do Poder Público, ao definir esses limites, deve sempre levar em conta a impossibilidade de disposição dos direitos ali presentes.

Contudo, o conteúdo do compromisso assinado excedeu os limites legalmente previstos.

Conforme inicialmente previsto na Resolução CONAMA 315/02, as montadoras possuíam prazo de três anos (2006-2009) para adequação dos veículos às novas exigências. No compromisso assinado o Poder Público permitiu que este prazo fosse dilatado em mais três anos, a partir de 2009, ficando nítida a ausência de qualquer exercício de ponderação por parte da Administração Pública.

Além da mitigação da obrigação nos três anos seguintes, o Poder Público autorizou que a implementação das medidas fosse realizada de acordo com os interesses das companhias. Em outras palavras, o Ministério Público Federal permitiu que entes privados escolhessem quais cidades seriam privilegiadas com melhor qualidade do ar em detrimento de outras. O direito à saúde, garantia fundamental do ser humano, constitucionalmente protegido, tutelado por inúmeras convenções internacionais, foi objeto de barganha neste compromisso. 
Ato como este, em momento algum, encontra respaldo na Constituição Cidadã de 1988. Não existe, em qualquer dos dispositivos constitucionais, mandamento que preveja tratamento desigual entre brasileiros, especialmente no que se refere à saúde. Realizar acordo que permita que apenas parte da população brasileira seja beneficiada, exclusivamente com base em interesses privados, traduz total desprezo pelos direitos constitucionais arduamente conquistados.

Em troca da mitigação e extensão do prazo, as montadoras ofereceram medidas compensatórias com valores irrisórios que, se comparadas com os gastos necessários para reparar os males causados pela poluição atmosférica oriunda de veículos automotores, não passam de mera gorjeta.

O ar atmosférico é bem difuso e a conservação de sua qualidade é essencial para a manutenção não só da vida humana, mas também de diversas espécies e ecossistemas. A poluição atmosférica deve ser vista como um problema de extrema gravidade sendo constantemente combatida através não só da intervenção estatal como também por meio da participação social.

Apesar de o compromisso de ajustamento de conduta ser um instrumento capaz de garantir a tutela ambiental de modo mais célere, para que atinja seu objetivo de forma integral deve prever a adequação por inteiro às exigências legais, sob pena de eventualmente se identificar que houve negociação de direito difuso.

A realização do compromisso de ajustamento de conduta que alterou o cronograma da Resolução CONAMA 315/02 não demonstra qualquer vitória por parte da sociedade. Pelo contrário, sua existência vai de encontro aos princípios e normas que regem o direito brasileiro, ficando demonstrado assim que houve verdadeira derrota para a sociedade.

A autoridade pública ao assinar este acordo se coaduna essencialmente com os interesses da indústria automobilística brasileira 
que, através dos argumentos aqui sucintamente apresentados, demonstra um total descaso para com a nossa sociedade. Assim, fica evidenciada a incapacidade do Poder Público de defender os interesses da população brasileira que diariamente padece em função da omissão do cumprimento desta norma.

Não obstante o ajuizamento da ação civil pública por parte do Ministério Público Estadual de São Paulo, a população brasileira e os demais órgãos públicos legitimados têm o dever, através dos meios constitucionalmente garantidos (e. g. ação popular, nova ação civil pública, pedido de anulação do compromisso ajustado), de questionar o descumprimento da Resolução CONAMA 315/02, tendo em vista o compromisso ajustado. 


\section{Bibliografia}

ABELHA, Marcelo. Ação civil pública e meio ambiente. $2^{\mathrm{a}}$ ed.. Rio de Janeiro: Forense Universitária, 2004.

AKAOUI, Fernando Reverendo Vidal. Compromisso de ajustamento de conduta ambiental. $2^{\mathrm{a}}$ ed. rev. e atual.. São Paulo: Editora Revista dos Tribunais, 2008.

ANTUNES, Paulo de Bessa. Direito Ambiental. $8^{\mathrm{a}}$ ed. rev., atual. e ampl.. Rio de Janeiro: Editora Lumen Juris, 2005.

BAHNEMANN, Wellington. Petrobrás vai reduzir enxofre no diesel. Disponível em http://www.idec.org.br/climaeconsumo/noticia.asp?id=9254. Acesso em 25.05.09.

CAPPELlETTI, Mauro; GARTH, Bryant. Acesso à justiça. Porto Alegre: Sergio Antonio Fabris Editor, 1988.

CARVALHO FILHO, José dos Santos. Ação civil pública: comentários por artigo. $7^{\mathrm{a}}$ ed. rev., atual., e ampl.. Rio de Janeiro: Editora Lumen Juris, 2009.

. Manual de direito administrativo. $19^{\mathrm{a}}$ ed. rev., atual. e ampl.. Rio de Janeiro: Editora Lumen Juris, 2008.

COSTA JR., Paulo José; MILARÉ, Édis. Direito penal ambiental: comentários a lei n. 9.605/98. Campinas: Editora Millennium, 2002.

CRUZ, Ana Paula Fernandes Nogueira da. A tutela ambiental do ar atmosférico. Rio de Janeiro: Editora Esplanada, 2002.

DERANI, Cristiane. Direito ambiental econômico. $3^{\mathrm{a}}$ ed. São Paulo: Editora Saraiva, 2008.

DERÍSIO, José Carlos. Introdução do controle de poluição ambiental. $1^{\mathrm{a}}$ ed.. São Paulo: CETESB, 1992.

ESTADO, Agência. Custo da poluição é de R\$14 por segundo, diz estudo. Disponível em http://www.estadao.com.br/geral/not_ger374498,0.htm. Acesso em 26.05.09. 
FAGUNDES, Miguel Seabra. O controle dos atos administrativos pelo Poder Judiciário. $7^{\mathrm{a}}$ ed. atual. por Gustavo Binenbojm. Rio de Janeiro: Editora Forense, 2006.

FERNANDES, Rodrigo. Compromisso de ajustamento de conduta ambiental: fundamentos, natureza jurídica, limites e controle jurisdicional. Rio de Janeiro: Editora Renovar, 2008.

FERREIRA, Helini Sivini. Os instrumentos jurisdicionais ambientais na constituição brasileira. In: CANOTILHO, José Joaquim Gomes; LEITE, José Rubens Morato (org.). Direito constitucional ambiental brasileiro. São Paulo: Saraiva, 2007.

FERREIRA FILHO, Manuel Gonçalves. Curso de direito constitucional. $32^{\mathrm{a}}$ ed. rev. e atual.. São Paulo: Editora Saraiva, 2006.

FIGUEIREDO, Guilherme José Purvin de. A propriedade no direito ambiental. Rio de Janeiro: Editora Esplanada, 2004.

FINK, Daniel Roberto. Alternativa à ação civil pública ambiental: reflexões sobre as vantagens do termo de ajustamento de conduta. In: MILARÉ, Édis (coord.). Ação civil pública - Lei 7.347/85 - 15 anos. São Paulo: Editora Revista dos Tribunais, 2001.

FIORILlO, Celso Antonio Pacheco. Princípios do direito processual ambiental. $3^{\text {a }}$ ed. rev., atual. e ampl.. São Paulo: Editora Saraiva, 2009.

GAVRONSKI, Alexandre Amaral. Das origens ao futuro da lei da ação civil pública: o desafio de garantir acesso à justiça com efetividade. In: MILARÉ, Édis (coord.). A ação civil pública após 20 anos: efetividade e desafios. São Paulo: Revista dos Tribunais, 2005.

LEITE, José Rubens Morato; LIMA, Maíra Luísa Milani de; FERREIRA, Maria Leonor Paes Cavalcanti. Ação civil pública, termo de ajustamento de conduta e formas de reparação do dano ambiental: reflexões para uma sistematização. In: MILARÉ, Édis (coord.). A ação civil pública após 20 anos: efetividade e desafios. São Paulo: Revista dos Tribunais, 2005.

. Dano ambiental: do individual ao coletivo extrapatrimonial. $2^{\mathrm{a}}$ ed. rev., atual. e ampl.. São Paulo: Editora Revista dos Tribunais, 2003. 
LENZA, Pedro. Teoria geral da ação civil pública. $3^{\mathrm{a}}$ ed. rev., atual. e ampl.. São Paulo: Editora Revista dos Tribunais, 2008.

LOVATO, Luiz Gustavo. A proteção à saúde no Brasil: aspectos sociais, econômicos e políticos. In: ASSIS, Araken de. (coord.). Aspectos polêmicos e atuais dos limites da jurisdição e do direito à saúde. $1^{\mathrm{a}}$ ed.. Rio Grande do Sul: Editora Notadez, 2007.

MACHADO, Paulo Affonso Leme. Direito ambiental brasileiro. $13^{\mathrm{a}}$ ed. rev., atual. e ampl.. São Paulo: Editora Malheiros, 2005.

MARTINS, Wal. Direito à saúde: compêndio. Belo Horizonte: Editora Fórum, 2008.

MAZZILLI, Hugo Nigro. A defesa dos interesses difusos em juizo: meio ambiente, consumidor, patrimônio cultural. Patrimônio público e outros interesses. $21^{\mathrm{a}}$ ed. rev., atual. e ampl. São Paulo: Editora Saraiva, 2008.

. Compromisso de ajustamento de conduta: evolução e fragilidades e atuação do Ministério Público. In: Revista de direito ambiental v. 41. São Paulo: Editora Revista dos Tribunais, 2006.

MEDAUAR, Odete. Controle da administração pública. $1^{\mathrm{a}}$ ed.. São Paulo: Editora Revista dos Tribunais, 1993.

MEIRELLES, Hely Lopes. Direito administrativo brasileiro. $35^{\text {a }}$ ed.. São Paulo: Editora Malheiros, 2009.

MELLO, Celso Antônio Bandeira de. Curso de direito administrativo. $26^{\mathrm{a}}$ ed. rev. e atual.. São Paulo: Editora Malheiros, 2008.

MILARÉ, Édis. O compromisso de ajustamento de conduta e a responsabilidade penal ambiental. In: MILARÉ, Édis (coord.). A ação civil pública após 20 anos: efetividade e desafios. São Paulo: Revista dos Tribunais, 2005.

. Direito do ambiente: doutrina, jurisprudência e glossário. $4^{\mathrm{a}}$ ed. rev., atual. e ampl.. São Paulo: Editora Revista dos Tribunais, 2005. MIRRA, Álvaro Luiz Valery. Ação civil pública e a reparação do dano ao meio ambiente. $2^{\mathrm{a}}$ ed. atual.. São Paulo: Editora Juarez de Oliveira, 2004. 
- Ação civil pública em defesa do meio ambiente: a representatividade adequada dos entes intermediários legitimados para a causa. In: MILARÉ, Édis (coord.). A ação civil pública após 20 anos: efetividade e desafios. São Paulo: Revista dos Tribunais, 2005.

PEREIRA, Caio Mário da Silva. Instituições de direito civil. V. 2. Teoria geral das obrigações. Rio de Janeiro: Editora Forense, 2005.

PETROBRÁS, Agência. Esclarecimentos sobre teor de enxofre e o óleo diesel S-50. Disponível em http://www.agenciapetrobrasdenoticiais.com.br/materia.asp?id editoria $=8 \&$ id noticia $=5932$. Acesso em 19.05.09.

PIETRO, Maria Sylvia Zanella di. Direito administrativo. $21^{\text {a }}$ ed. São Paulo: Editora Atlas, 2008.

PRADO, Luiz Regis. Direito penal do ambiente: meio ambiente, patrimônio cultural, ordenação do território e biossegurança (com a análise da Lei n. 11.105/2005). São Paulo: Editora Revista dos Tribunais, 2005.

PRADO JUNIOR, Caio. História econômica do Brasil. 45a reimpr.. São Paulo: Editora Brasiliense, 1998.

RODRIGUES, Geisa de Assis. Ação civil pública e termo de ajustamento de conduta: teoria e prática. Rio de Janeiro: Editora Forense, 2006.

SANGIOVANNI, Ricardo. Poluição de carros quadriplica risco de morte. Disponível em http://www.nossasaopaulo.org.br/portal/node/2569. Acesso em 19.05.09.

SCHWARTZ, Germano. Direito à saúde: efetivação em uma perspectiva sistêmica. Porto Alegre: Livraria do Advogado, 2001.

SILVA, José Afonso da. Direito ambiental constitucional. $7^{\mathrm{a}}$ ed. São Paulo: Editora Malheiros, 2009.

Curso de direito constitucional positivo. $26^{\mathrm{a}}$ ed. rev. e atual.. São Paulo: Editora Malheiros, 2006.

SILVEIRA, Julliane. Poluição aumenta risco de desenvolver doença autoimune.

Disponível em 
http://www1.folha.uol.com.br/folha/ambiente/ult10007u558384.shtml.

Acesso em 19.05.09.

VEIGA, José Eli da. Desenvolvimento sustentável: o desafio do século XXI. Rio de Janeiro: Editora Garamond, 2005. 


\section{Bibliografia}

ABELHA, Marcelo. Ação civil pública e meio ambiente. $2^{\mathrm{a}}$ ed.. Rio de Janeiro: Forense Universitária, 2004.

AKAOUI, Fernando Reverendo Vidal. Compromisso de ajustamento de conduta ambiental. $2^{\mathrm{a}}$ ed. rev. e atual.. São Paulo: Editora Revista dos Tribunais, 2008.

ANTUNES, Paulo de Bessa. Direito Ambiental. $8^{\text {a }}$ ed. rev., atual. e ampl.. Rio de Janeiro: Editora Lumen Juris, 2005.

BAHNEMANN, Wellington. Petrobrás vai reduzir enxofre no diesel. Disponível em http://www.idec.org.br/climaeconsumo/noticia.asp?id=9254. Acesso em 25.05.09.

CAPPELLETTI, Mauro; GARTH, Bryant. Acesso à justiça. Porto Alegre: Sergio Antonio Fabris Editor, 1988.

CARVAlHO FILHO, José dos Santos. Ação civil pública: comentários por artigo. $7^{\text {a }}$ ed. rev., atual., e ampl.. Rio de Janeiro: Editora Lumen Juris, 2009. . Manual de direito administrativo. $19^{\mathrm{a}}$ ed. rev., atual. e ampl.. Rio de Janeiro: Editora Lumen Juris, 2008.

COSTA JR., Paulo José; MILARÉ, Édis. Direito penal ambiental: comentários a lei n. 9.605/98. Campinas: Editora Millennium, 2002.

CRUZ, Ana Paula Fernandes Nogueira da. A tutela ambiental do ar atmosférico. Rio de Janeiro: Editora Esplanada, 2002.

DERANI, Cristiane. Direito ambiental econômico. $3^{\text {a }}$ ed. São Paulo: Editora Saraiva, 2008.

DERÍSIO, José Carlos. Introdução do controle de poluição ambiental. $1^{\mathrm{a}}$ ed.. São Paulo: CETESB, 1992.

ESTADO, Agência. Custo da poluição é de R\$14 por segundo, diz estudo. Disponível em http://www.estadao.com.br/geral/not_ger374498,0.htm. Acesso em 26.05.09.

FAGUNDES, Miguel Seabra. $O$ controle dos atos administrativos pelo Poder Judiciário. $7^{\mathrm{a}}$ ed. atual. por Gustavo Binenbojm. Rio de Janeiro: Editora Forense, 2006. 
FERNANDES, Rodrigo. Compromisso de ajustamento de conduta ambiental: fundamentos, natureza jurídica, limites e controle jurisdicional. Rio de Janeiro: Editora Renovar, 2008.

FERREIRA, Helini Sivini. Os instrumentos jurisdicionais ambientais na constituição brasileira. In: CANOTILHO, José Joaquim Gomes; LEITE, José Rubens Morato (org.). Direito constitucional ambiental brasileiro. São Paulo: Saraiva, 2007.

FERREIRA FILHO, Manuel Gonçalves. Curso de direito constitucional. $32^{\mathrm{a}}$ ed. rev. e atual.. São Paulo: Editora Saraiva, 2006.

FIGUEIREDO, Guilherme José Purvin de. A propriedade no direito ambiental. Rio de Janeiro: Editora Esplanada, 2004.

FINK, Daniel Roberto. Alternativa à ação civil pública ambiental: reflexões sobre as vantagens do termo de ajustamento de conduta. In: MILARÉ, Édis (coord.). Ação civil pública - Lei 7.347/85 - 15 anos. São Paulo: Editora Revista dos Tribunais, 2001.

FIORILLO, Celso Antonio Pacheco. Princípios do direito processual ambiental. $3^{a}$ ed. rev., atual. e ampl.. São Paulo: Editora Saraiva, 2009.

GAVRONSKI, Alexandre Amaral. Das origens ao futuro da lei da ação civil pública: o desafio de garantir acesso à justiça com efetividade. In: MILARÉ, Édis (coord.). A ação civil pública após 20 anos: efetividade e desafios. São Paulo: Revista dos Tribunais, 2005.

LEITE, José Rubens Morato; LIMA, Maíra Luísa Milani de; FERREIRA, Maria Leonor Paes Cavalcanti. Ação civil pública, termo de ajustamento de conduta e formas de reparação do dano ambiental: reflexões para uma sistematização. In: MILARÉ, Édis (coord.). A ação civil pública após 20 anos: efetividade e desafios. São Paulo: Revista dos Tribunais, 2005. . Dano ambiental: do individual ao coletivo extrapatrimonial. $2^{\mathrm{a}}$ ed. rev., atual. e ampl.. São Paulo: Editora Revista dos Tribunais, 2003.

LENZA, Pedro. Teoria geral da ação civil pública. $3^{\mathrm{a}}$ ed. rev., atual. e ampl.. São Paulo: Editora Revista dos Tribunais, 2008. 
LOVATO, Luiz Gustavo. A proteção à saúde no Brasil: aspectos sociais, econômicos e políticos. In: ASSIS, Araken de. (coord.). Aspectos polêmicos e atuais dos limites da jurisdição e do direito à saúde. $1^{\mathrm{a}}$ ed.. Rio Grande do Sul: Editora Notadez, 2007.

MACHADO, Paulo Affonso Leme. Direito ambiental brasileiro. 13 ${ }^{\mathrm{a}}$ ed. rev., atual. e ampl.. São Paulo: Editora Malheiros, 2005.

MARTINS, Wal. Direito à saúde: compêndio. Belo Horizonte: Editora Fórum, 2008 .

MAZZILli, Hugo Nigro. A defesa dos interesses difusos em juízo: meio ambiente, consumidor, patrimônio cultural. Patrimônio público e outros interesses. 21 ${ }^{\mathrm{a}}$ ed. rev., atual. e ampl. São Paulo: Editora Saraiva, 2008.

- Compromisso de ajustamento de conduta: evolução e fragilidades e atuação do Ministério Público. In: Revista de direito ambiental v. 41. São Paulo: Editora Revista dos Tribunais, 2006.

MEDAUAR, Odete. Controle da administração pública. $1^{\mathrm{a}}$ ed.. São Paulo: Editora Revista dos Tribunais, 1993.

MEIRELLES, Hely Lopes. Direito administrativo brasileiro. $35^{\mathrm{a}}$ ed.. São Paulo: Editora Malheiros, 2009.

MELlO, Celso Antônio Bandeira de. Curso de direito administrativo. $26^{\mathrm{a}}$ ed. rev. e atual.. São Paulo: Editora Malheiros, 2008.

MILARÉ, Édis. O compromisso de ajustamento de conduta e a responsabilidade penal ambiental. In: MILARÉ, Édis (coord.). A ação civil pública após 20 anos: efetividade e desafios. São Paulo: Revista dos Tribunais, 2005. . Direito do ambiente: doutrina, jurisprudência e glossário. $4^{\mathrm{a}}$ ed. rev., atual. e ampl.. São Paulo: Editora Revista dos Tribunais, 2005.

MIRRA, Álvaro Luiz Valery. Ação civil pública e a reparação do dano ao meio ambiente. $2^{\mathrm{a}}$ ed. atual.. São Paulo: Editora Juarez de Oliveira, 2004.

Ação civil pública em defesa do meio ambiente: a representatividade adequada dos entes intermediários legitimados para a causa. In: MILARÉ, Édis (coord.). A ação civil pública após 20 anos: efetividade e desafios. São Paulo: Revista dos Tribunais, 2005. 
PEREIRA, Caio Mário da Silva. Instituições de direito civil. V. 2. Teoria geral das obrigações. Rio de Janeiro: Editora Forense, 2005.

PETROBRÁS, Agência. Esclarecimentos sobre teor de enxofre e o óleo diesel S50 . Disponível

em http://www.agenciapetrobrasdenoticiais.com.br/materia.asp?id_editoria=8\&id_n oticia $=5932$. Acesso em 19.05.09.

PIETRO, Maria Sylvia Zanella di. Direito administrativo. $21^{a}$ ed. São Paulo: Editora Atlas, 2008.

PRADO, Luiz Regis. Direito penal do ambiente: meio ambiente, patrimônio cultural, ordenação do território e biossegurança (com a análise da Lei $n$. 11.105/2005). São Paulo: Editora Revista dos Tribunais, 2005.

PRADO JUNIOR, Caio. História econômica do Brasil. 45ª reimpr.. São Paulo: Editora Brasiliense, 1998.

RODRIGUES, Geisa de Assis. Ação civil pública e termo de ajustamento de conduta: teoria e prática. Rio de Janeiro: Editora Forense, 2006.

SANGIOVANNI, Ricardo. Poluição de carros quadriplica risco de morte. Disponível em http://www.nossasaopaulo.org.br/portal/node/2569. Acesso em 19.05.09.

SCHWARTZ, Germano. Direito à saúde: efetivação em uma perspectiva sistêmica. Porto Alegre: Livraria do Advogado, 2001.

SILVA, José Afonso da. Direito ambiental constitucional. $7^{\text {a }}$ ed. São Paulo: Editora Malheiros, 2009.

. Curso de direito constitucional positivo. $26^{\mathrm{a}}$ ed. rev. e atual.. São Paulo: Editora Malheiros, 2006.

SILVEIRA, Julliane. Poluição aumenta risco de desenvolver doença autoimune. Disponível em http://www1.folha.uol.com.br/folha/ambiente/ult10007u558384.shtml. Acesso em 19.05.09.

VEIGA, José Eli da. Desenvolvimento sustentável: o desafio do século XXI. Rio de Janeiro: Editora Garamond, 2005. 